\title{
Lessons for Responsible Innovation in the Business Context: A Systematic Literature Review of Responsible, Social and Sustainable Innovation Practices
}

\author{
Rob Lubberink ${ }^{1, *}$, Vincent Blok ${ }^{1}$, Johan van Ophem ${ }^{2}$ and Onno Omta ${ }^{1}$ \\ 1 Department of Management Studies, Wageningen University, 6706 KN Wageningen, The Netherlands; \\ vincent.blok@wur.nl (V.B.); onno.omta@wur.nl (O.O.) \\ 2 Department of Economics of Consumers and Households, Wageningen University, 6706 KN Wageningen, \\ The Netherlands; johan.vanophem@wur.nl \\ * Correspondence: rob.lubberink@wur.nl; Tel.: +31-317-482372
}

Academic Editor: Marc A. Rosen

Received: 7 February 2017; Accepted: 25 April 2017; Published: 5 May 2017

\begin{abstract}
This paper aims to contribute to the ongoing conceptual debate on responsible innovation, and provides innovation practices and processes that can help to implement responsible innovation in the business context. Based on a systematic literature review of 72 empirical scholarly articles, it was possible to identify, analyse and synthesise empirical findings reported in studies on social, sustainable and responsible innovation practices in the business context. The synthesis of the included articles resulted in a refined framework for responsible innovation in the business context. This framework includes an overview of innovation practices and processes that can enhance the dimensions of responsible innovation: anticipation, reflexivity, inclusion, deliberation, responsiveness and knowledge management. Additionally, knowledge gaps are identified and a research agenda for responsible innovation is proposed. This review can therefore serve as a next step in the theoretical and practical development of responsible innovation in general, and in the business context in particular.
\end{abstract}

Keywords: responsible research and innovation; social innovation; sustainable innovation; sustainability; governance; industry; entrepreneurship

\section{Introduction}

Societies all over the world are facing grand societal challenges such as food security, ageing populations, energy demand and climate change. Nowadays, private industry is seen not only as part of the problem that societies face, but they are increasingly considered to be key for finding and developing solutions for societal challenges. Governments all over the world are therefore encouraging innovation in private industry [1], as innovation and technological development are increasingly seen as the panacea for big societal challenges [2].

However, one can question whether innovation is inherently good [2]. There is always the probability that innovations have unforeseen consequences [3]. For example, the effective insecticide DDT turned out to have detrimental consequences for the ecosystem over the long term. Innovations can have short-term advantages, but also come with dilemmas, questions and uncertainties regarding their development and their future implications. This especially holds true for innovations that are disruptive, complex and hard to understand for non-experts [4]. Even the most promising innovations can fail because the ethical and societal concerns that come with innovation are not properly taken into account [5]. 
Responsible innovation is a new concept that builds on governance approaches and innovation assessments that aim to take these ethical and societal concerns into account at the start of the innovation process. The main idea behind responsible innovation is to democratise innovation [6-8] and realise deliberative forms of governance such as stakeholder and public engagement [3]. Stakeholders and members of the public are involved upstream in the innovation process and encouraged to deliberate about the multiple futures and uncertainties that the innovation could bring or seeks to bring. This upstream inclusion of stakeholders and the public, by deliberative forms of governance, can help to realise a collective responsibility to control and direct innovation into a direction that is ethically acceptable, societally desirable and sustainable [9]. This is expected to enhance the chance of innovation adoption, better embed the innovation in society, and ensure that the innovation delivers societal benefits [5]. Therefore, Stilgoe et al. [3] define responsible innovation as "taking care of the future through collective stewardship of science and innovation in the present" (p. 3) and in broader terms as 'innovation with society and innovation for society' [10].

However, the problem with the current concept of responsible innovation is that it is developed by researchers and policy makers [11] who are focused primarily on the conduct of responsible science and technological development [12] without differentiating between research, development and commercialisation [13]. This poses important challenges for the implementation of responsible innovation in the business context. First of all, focusing on science and technological development indicates a narrow view on innovation as other types of innovation are not considered, such as social innovations [14]. Second of all, commercialisation is an essential stage within the innovation process [15]. Commercially-driven innovation processes differ from those in research due to the priority given to achieving economic impact. Furthermore, the interests and values of innovators in the business context may differ from others (e.g., researchers in academia) and Research and Development departments face different constraints regarding confidentiality and public image [5]. Therefore, the question still remains as to how the current concept of responsible innovation can be implemented in the business context.

Responsible innovation is a rather new and emerging concept and documentation of its implementation in the business context is still scarce. However, documentation about related investigations in the fields of social and sustainable innovation in the business context is more common $[1,16,17]$. Like responsible innovation, social and sustainable innovation also aim to respond to overarching societal challenges. Furthermore, they require the involvement of multiple stakeholders, and they consider social and environmental impact in addition to economic impact as desirable innovation outcomes [18]. The scientific documentation of social and sustainable innovation in the business context can be informative for the conceptualisation and understanding of responsible innovation in the business context.

Therefore, the purpose of this paper is to identify innovation practices and processes that can help to implement responsible innovation in the business context, given the current political and socioeconomic system. Even though it is highly relevant to reflect upon the political and socioeconomic system and how it relates to responsible innovation, it goes beyond the scope of this review. The purpose of this review is met by identifying, analysing and synthesising findings in empirical studies that have reported social, sustainable and responsible innovation practices and processes in the business context. This can subsequently be used to provide guidance on achieving responsible innovation in the business context. To this end, we follow a similar review approach in this article as is published in Adams et al. [1], which consists of three stages:

1. Stage 1: Developing an initial architecture for reviewing responsible innovation. Drawing primarily on the governance framework of responsible innovation developed by Stilgoe et al. [3], we describe the initial conceptual framework for responsible innovation. This initial framework forms the basis for identifying, analysing, and synthesising the innovation practices and processes that are presented in the findings from included studies. Since responsible innovation is developed in a European context, and cannot be used as an a priori framework beyond this context [7], 
we delimited this review to articles that report empirical research of innovation practices and processes in the 'global North'.

2. Stage 2: Systematic review of responsible innovation practices in the business context. We systematically review $[19,20]$ the literature on responsible, social and sustainable innovation in the business context published between 1999 and 2015. Social and sustainable innovation are included since documentation of responsible innovation practices in the business context is scarce, and social and sustainable innovation share conceptual similarities with responsible innovation when it comes to their input, throughput, and output of innovation. The conceptual overlap is more elaborately explained in stage 1.

3. Stage 3: Framework synthesis. We adopt a framework synthesis methodology for our systematic literature review where we aim to refine and give practical substance to the initial framework for the responsible innovation presented in stage 1 . This refinement is based on a synthesis of innovation practices and processes reported in the findings of included empirical studies. This leads to a refined framework that is supported with innovation practices and processes that firms can implement to realise responsible innovation in the business context.

The remainder of this article is structured in the following way. In stage 1, we present a brief outline of the literature on responsible innovation and elaborate upon its dimensions. These dimensions form the building blocks of the initial 'architecture' for reviewing responsible innovation. Subsequently, the concepts of social innovation and sustainable innovation are explained and supported with argumentation as to why they overlap conceptually with responsible innovation. In stage 2, we explain the scope of the review, the research design, quality appraisal, and the synthesis approach. This is followed by stage 3 , where we present the innovation activities that help to implement each dimension of responsible innovation in the business context. The paper concludes with a discussion on the implications of our findings for researchers and practitioners interested in responsible innovation in the business context.

\section{Stage 1: Developing an Initial Architecture for Reviewing Responsible Innovation}

\subsection{Responsible Innovation}

Responsible innovation is a new concept that is developed and introduced in a top-down manner by policy makers and scientists [21]. However, the concept is interpretively flexible and there are competing narratives. Burget et al. reviewed the literature on responsible innovation and observed that policy makers and scientists defined and conceptualised responsible innovation in different ways [11]. After analysing and synthesising the literature, they conclude that: "Responsible Innovation is essentially an attempt to govern research and innovation in order to include all the stakeholders and the public in the early stages of research and development. The inclusion of different actors and the public is, in turn, meant to increase the possibilities to anticipate and discern how research and innovation can or may benefit society as well as prevent any negative consequences from happening" (p. 15).

Owen et al. [10] and Stilgoe et al. [3] focus on achieving a democratic governance framework for innovation that is based on reflecting on the purpose(s) of the innovation as well as focusing on avoiding detrimental implications [5]. Von Schomberg [9] has a similar focus on a democratic governance of innovation, and defines this process (i.e., the throughput) as: " . . a transparent, interactive process by which societal actors and innovators become mutually responsive to each other with a view to the (ethical) acceptability, sustainability and societal desirability of the innovation process and its marketable products (in order to allow a proper embedding of scientific and technological advances in our society)" (p. 9).

What does this mean for the initial architecture that is used to review the responsible innovation literature? Although different approaches to responsible innovation exist [11,22,23], such as Technology Assessment and Impact Assessment [5], the framework for responsible innovation developed by Owen et al. [10] and Stilgoe et al. [3] is one of the most dominant approaches in responsible innovation literature $[5,11]$. Their framework consists of four dimensions: anticipation, reflexivity, inclusion and 
deliberation, and responsiveness. These four dimensions can be used heuristically for anticipatory governance of innovation, and are the characteristics of a more responsible vision of innovation [3]. The fact that these dimensions are recurring throughout responsible innovation literature underwrites the influential role that their framework has in the field of responsible innovation [11]. Therefore, these four dimensions are used as building blocks for our initial architecture to review responsible innovation practices.

\subsubsection{Anticipation}

Anticipation involves systematic thinking about any known, likely, plausible and possible implications of the innovation that is to be developed [3], which requires that innovators understand the dynamics that help to shape the innovation [11]. The aim is to envision desirable futures-because futures cannot be predicted-and organise resources to steer the innovations in the right direction. This requires early inclusion of stakeholders and the wider public who engage in "a dedicated attempt to anticipate potential problems, assess available alternatives" [23].

\subsubsection{Reflexivity}

Reflexivity is about critically scrutinising one's own activities, commitments and assumptions, and being aware of the limits of knowledge and the fact that one's reality might not be universally held [3]. Furthermore, innovators are expected to engage in second-order reflexivity, where they scrutinise how their underlying value systems and beliefs influence the development of the innovation. In the end, innovators should not only live up to their role responsibility but also their wider moral responsibilities [3,24]. Reflexivity can be enhanced by early inclusion of stakeholders and the public who deliberate about the innovation at stake [23].

\subsubsection{Inclusion and Deliberation}

Inclusion and deliberation resonate in all articles on responsible innovation, as they are associated with other dimensions [11]. It is about the upstream engagement of stakeholders and the wider public to open up discussions and to interrogate the social, political and ethical implications that the development of the innovation would bring [3]. One could say that responsible innovation involves an "active engagement of stakeholders for the purpose of substantively better decision-making and mutual learning" [23].

Inclusion and deliberation are used interchangeably in the articles by Stilgoe et al. [3] and Owen et al. [6]. However, Pellé and Reber [13] question this lack of distinction between inclusion and deliberation in responsible innovation literature. Stakeholder inclusion and deliberation can have competing objectives and can therefore even be in conflict with each other [25]. Van de Kerkhof [26] states that "deliberation refers to a process of argumentation and communication in which the participants engage into an open process in which they exchange opinions and viewpoints, weigh and balance arguments, and offer reflections and associations" (p. 282). Therefore, one could say that stakeholder inclusion focuses more on questions surrounding who to involve, during which stage of the innovation process, and whether the stakeholder network is representative. On the other hand, deliberation focuses more on the actual discussions that should lead to decision-making, and pays less attention to obstacles for inclusion or representativeness of the stakeholder network [25]. The political part of deliberation is central to responsible innovation, and ideally stakeholders would be able to negotiate the terms of their inclusion and deliberation, including the politics of deliberative engagement. For example, they would be able to discuss the substantive bias in responsible innovation that ethical concerns outweigh economic concerns [27].

\subsubsection{Responsiveness}

Responsiveness is about having the capacity to change the shape or direction of the innovation in response to values of stakeholders and the wider public. Furthermore, it requires a collective 
institutionalised response and co-responsibility for responsible development of the innovation [6] in the light of new knowledge, perspectives, views and norms that emerge during the innovation process. In other words, there should be "a willingness among all participants to act and adapt according to these ideas" [23].

\subsection{Social Innovation}

Social innovation is a commonly but not consistently used term by scientists [28] as it is conceptualised and defined in different ways [16,29] by different streams of scholars [30]. The term is used as synonymous for intended and unintended social change, while it is used as a synonym for intangible innovations as well. However, after reviewing the literature on social innovation, Choi and Majumdar (2014) were able to conceptualise social innovation in the entrepreneurial context [16]. They state that social innovations are: "explicitly aiming at the creation of social value and thus at positive social change. Hence, in this case, the 'social' denotes that the purpose of social innovation is to meet pressing social needs and to improve human and environmental well-being" (p. 27).

Lubberink et al. [18] identified conceptual similarities and dissimilarities between responsible, social and sustainable innovation based on a conceptual analysis of published literature reviews of these three innovation concepts. They conclude that social innovation overlaps conceptually with responsible innovation, especially when it comes to the drivers for innovation and the outcomes of social innovation processes. For example, social innovations are also driven by the desire to solve grand challenges and to respond to pressing social needs. Furthermore, social innovation aims to enhance social and/or environmental well-being. Stakeholder engagement and deliberative approaches also take place in social innovation. For example, less formalised social innovations are often developed based on co-creation with target beneficiaries [16]. Furthermore, social innovation can expand the narrow view of innovation that can be found in responsible innovation literature. The literature review by Choi and Majumdar (2014) [16] provides an overview of the different types of innovation outcomes.

The fact that social innovation can serve as a useful resource for our understanding of responsible innovation does not only ensue from its conceptual similarities. Social innovation is not a new phenomenon [2,31], and it is conceptualised and defined by practitioners [17]. As a result, research on social innovation is often practice-oriented [16]. Due to the conceptual overlap, and the fact that it is documented in the business context, we argue that studies on social innovation in the business context can serve as an important resource for studying responsible innovation practices in the business context.

\subsection{Sustainable Innovation}

Sustainable innovation is a concept consisting of several approaches to sustainability-related innovation such as green, eco, environmental and sustainable innovation [32,33]. Schiederig et al. (2012) reviewed the literature on sustainability-related innovation and concluded that sustainable innovations appear in different forms including products, processes, services and business models [32]. They have a market orientation, meaning that they satisfy needs and are competitive on the market. The motivations to engage in sustainable innovation can be economic or ecological. Furthermore, sustainable innovations reduce environmental impact and preferably have no negative environmental impact at all. The full life-cycle of the innovation should be considered to assess the environmental impact. In the end, they can set new standards of sustainability for firms [32].

Based on a conceptual analysis of literature reviews on responsible and sustainable innovation, Lubberink et al. [18] came to the conclusion that sustainable innovation overlaps conceptually with responsible innovation. Sustainable innovations are also initiated in response to grand societal challenges, and commonly climate-change-related challenges. Furthermore, sustainable innovation increasingly addresses complex challenges which require the development of complex systems-shaping solutions. Adams et al. (2016) state that these solutions require workable relationships with a complex network of stakeholders [1]. In exemplary cases of sustainable innovation, these often include actors 
beyond the conventional value chain. Managing such a stakeholder network enables engagement in a dialogue, to gain legitimacy, to acquire necessary knowledge and to find opportunities for responsive solutions [1]. However, not only Lubberink et al. [18] but also Adams et al. [1] explicitly state that sustainable and responsible innovation are both focused on sustainability as a desirable outcome of innovation. Studies regarding green and eco innovation research are primarily focused on the environmental and economic dimensions as innovation outcomes [33]. However, sustainable innovation responds to the 'triple-bottom-line' and increasingly integrates the social dimension of sustainability in innovation processes and subsequent outcomes as well [1]. Therefore, it can be concluded that both responsible innovation and sustainable innovation not only take the economic and environmental dimension into account as innovation outcomes but also the social dimension.

The fact that sustainable innovation can serve as a useful resource for our understanding of responsible innovation does not only ensue from its conceptual similarities. The fact that corporate sustainable innovation has already received considerable attention from researchers, managers, and policy makers [1] is another important reason. Due to the conceptual overlap, and the fact that sustainable innovation is already widely documented in the business context, we argue that studies on sustainable innovation can serve as important resources for studying responsible innovation practices in the business context. An overview of the conceptual differences and similarities between the three innovation concepts can be found in Table A1 in the Appendix A.

\section{Stage 2: Systematic Review of Innovation Activities for Responsible Innovation}

\subsection{Methodology}

In this article, we conduct a systematic literature review of empirical research on social, sustainable and responsible innovation. This means that an algorithm was used to search for the empirical literature and the subsequent critical appraisal of the literature. Since this approach is transparent and reproducible, it enhances the quality of the review process and its findings [34]. There are five steps that need to be taken to produce a systematic literature review [19]. Following Denyer and Tranfield (2009), this means that in this review we address: question formulation; locating studies; study selection and evaluation; analysis and synthesis; and reporting the results. Supplementary information regarding this systematic literature review can be found in the supplementary file.

\subsubsection{Question Formulation}

This systematic literature review is based on reported innovation activities coming from empirical studies in the business context. These empirical studies should include an investigation of responsible, social or sustainable innovations developed with society or that are for society. More specifically, they involve an evidence-based investigation of innovation activities (and underlying mechanisms) that foster the implementation of: anticipation, reflexivity, inclusion, deliberation, and responsiveness during innovation practices in the business context.

The data analysis approach that forms the basis of the review depends on the review objective. The objective is to answer the following research question: 'What are the innovation activities firms engage in that help to implement the dimensions of responsible innovation?' The following review questions were therefore guiding the analysis:

- What innovation activities are reported by researchers who empirically investigated responsible, social and sustainable innovation in the business context?

- Which of these activities are beneficial for the implementation of responsible innovation dimensions?

- What are the mechanisms at play behind these innovation activities?

Corresponding with the nature of these review questions, we chose to pursue a more qualitative analysis of the results that are reported in the empirical studies. Therefore, a descriptive methodology 
is more appropriate as opposed to the statistical methods that can be found in meta-analyses. Furthermore, the collected data (i.e., the results reported in the empirical studies) are primarily qualitative by nature, which requires a corresponding data analysis and synthesis approach.

\subsubsection{Locating Studies}

The search strategy started with a background search to explore the literature, which was followed by an initial investigation as to whether the empirical evidence in the articles was appropriate for answering our questions. Given the plurality of meanings and usages of the terms responsible, social and sustainable innovation, we made sure that the search strings encompassed a variety of keywords in combination with Boolean operators (see Figure A1 in Appendix A). The keywords and search strings were developed and refined in collaboration with a research methodologist specialised in systematic literature reviews. The keywords were determined based on the expertise of the researchers, and additionally a thesaurus was consulted to include other related keywords. Subsequently, the comprehensive literature search was conducted based on three predefined algorithms (These algorithms were adapted to fit each electronic database, as the search mechanisms behind each of these electronic databases are slightly different).

This review involves a systematic literature search through various databases. The electronic databases that were used are: Scopus, Web of Science and Abi/Inform, with the latter especially covering business studies. The Bielefeld Academic Search Engine was used to access the grey literature in the emerging field of responsible innovation research. Furthermore, the non-indexed Journal of Responsible Innovation was hand-searched for evidence of responsible innovation in the business context, as well as a special issue on 'responsible innovation in the private sector' in the Journal on Chain and Network Science. Furthermore, since a systematic literature review is a time-consuming scientific activity, there is an inherent timespan between the latest systematic search for the literature review and the submission for publication. Because responsible innovation is a new and upcoming concept, this means that some articles are published after the systematic search for the literature was conducted. Therefore, a non-systematic literature search took place at the time of submission to identify, analyse and synthesise the latest empirical articles that investigated responsible innovation in the business context. The insights obtained from this non-systematic literature review are presented in the discussion.

\subsubsection{Study Selection/Evaluation}

The document types that are included in the review are: articles, review articles of empirical studies, conference papers, articles-in-press and relevant chapters published in books. The inclusion criteria are: articles based on empirical research; companies that are included as research subjects; articles that address responsible, social or sustainable innovation; articles that involve Corporate Social Responsibility (CSR) related to innovation management. The exclusion criteria are: articles written in languages other than English, German and Dutch (due to proficiency of the authors); articles on policy making, education, economics or CSR not related to innovation; articles that do not pass the quality appraisal. Furthermore, this review is delimited to the 'global North' and articles in research contexts beyond the United States, Canada, Europe, Australia and New Zealand were therefore excluded, since responsible innovation should be sensitive to the socio-political context in which innovation takes place [7].

The articles that were retrieved were screened for appropriateness based on the title, abstract and keywords. Three researchers independently screened a subset of 75 articles for appropriateness based on the inclusion and exclusion criteria. Discussions took place between the researchers when differences were encountered in terms of inclusion or exclusion of articles. This was done until an interrater agreement of at least $80 \%$ of the articles was reached. The corresponding author subsequently continued the screening of the data based on the results of the discussion. The articles that passed the title-abstract-keywords screening were subject to quality appraisal. 
The quality appraisal criteria in a realist synthesis are subordinate to the usage and usability of the selected study, hence the contribution that a paper can make to the data synthesis $[35,36]$. Therefore, similar to the realist synthesis by Walshe and Luker [36], this study adopts the same four questions proposed by Boaz and Ashby [37] for the quality appraisal: (1) Is the research presented in such a way that it can be appraised and used by others? (2) Is the research methodologically well executed? (3) Does the research approach match the defined purpose of the study? (4) Does the research address important innovation questions in a way that is both useful and useable? The articles were first appraised based on usefulness and usability (question 4). Studies that did not match the purpose of this review were excluded and therefore also not assessed based on the other three appraisal questions.

\subsubsection{Analysis/Synthesis}

In line with Rycroft-Malone et al. [38], we started by extracting the data and clustering it into evidence tables. The initial 'architecture' for reviewing the literature was used for extracting the data and subsequent clustering in evidence tables. Hence, innovation activities that were associated with anticipation (e.g., double flow scenario method [39]) were clustered under this label. Accordingly, the same was done for innovation activities that could enhance reflexivity, inclusion, deliberation and responsiveness. This was done with the help of Atlas.ti software package, which allows labels to be assigned to the activities that were described in the findings of the empirical articles. Furthermore, it allows these labels to be clustered, and can generate an evidence table with the data clustered for each individual dimension.

Subsequently, the evidence for each dimension was investigated to understand the attributes of the innovation activities, the context in which it is implemented, and what their benefits are. This way of working made it possible to look for connections across the data and themes to get a cumulative picture of the activities that were described in the different empirical papers. Subsequently, this allowed us to analyse and synthesise evidence-based innovation activities that help to implement the dimensions of responsible innovation in the business context. The formulation of these activities is presented in the results of this review article.

\subsection{Descriptive Summary}

The initial search for literature resulted in 1210 articles. The title, abstract and keywords were downloaded for each of these 1210 articles. There were subsequently 955 articles excluded based on the inclusion and exclusion criteria. Full paper assessments were done on the remaining 255 articles; of which 90 articles did not meet the inclusion and 20 papers could not be fully obtained via internet or libraries. The quality appraisal was therefore done on 145 full papers. There were 19 articles that did not meet the quality criteria proposed by Boaz and Ashby [37]. Another 58 articles were not considered useful and/or usable after appraisal. During the final stages of the review, the literature search and appraisal was repeated for new publications in the field of responsible innovation, as the literature base in this field is growing significantly. The relevant articles were subject to quality appraisal. This has ultimately led to the inclusion of four additional articles. Therefore, the data analysis for the realist synthesis is based on 72 articles. The graphical representation of this process is shown in Figure 1.

The included articles are widely distributed when it comes to the type of innovation studied, the origin of the companies studied, and the size of the companies studied. Of the academic literature, there were 34 articles that presented findings on sustainable innovation. There were 26 articles that presented findings on social innovation, and 12 studies focused on responsible innovation. The majority of the papers $(n=42)$ were based on European companies, while studies including only American companies were underrepresented $(n=13)$. There were 14 studies that were conducted based on data coming from companies from multiple continents.

Within the sample there was a relatively even distribution when it comes to the type of companies that are studied. The majority of the articles focused on systems of innovation in which private industry is participating $(n=23)$, while 20 articles focused on large firms and 15 studied small and/or medium 
sized enterprises (SMEs). Studies that focused on both large firms and SMEs $(n=6)$ or that did not define the type of companies investigated $(n=8)$ were underrepresented.

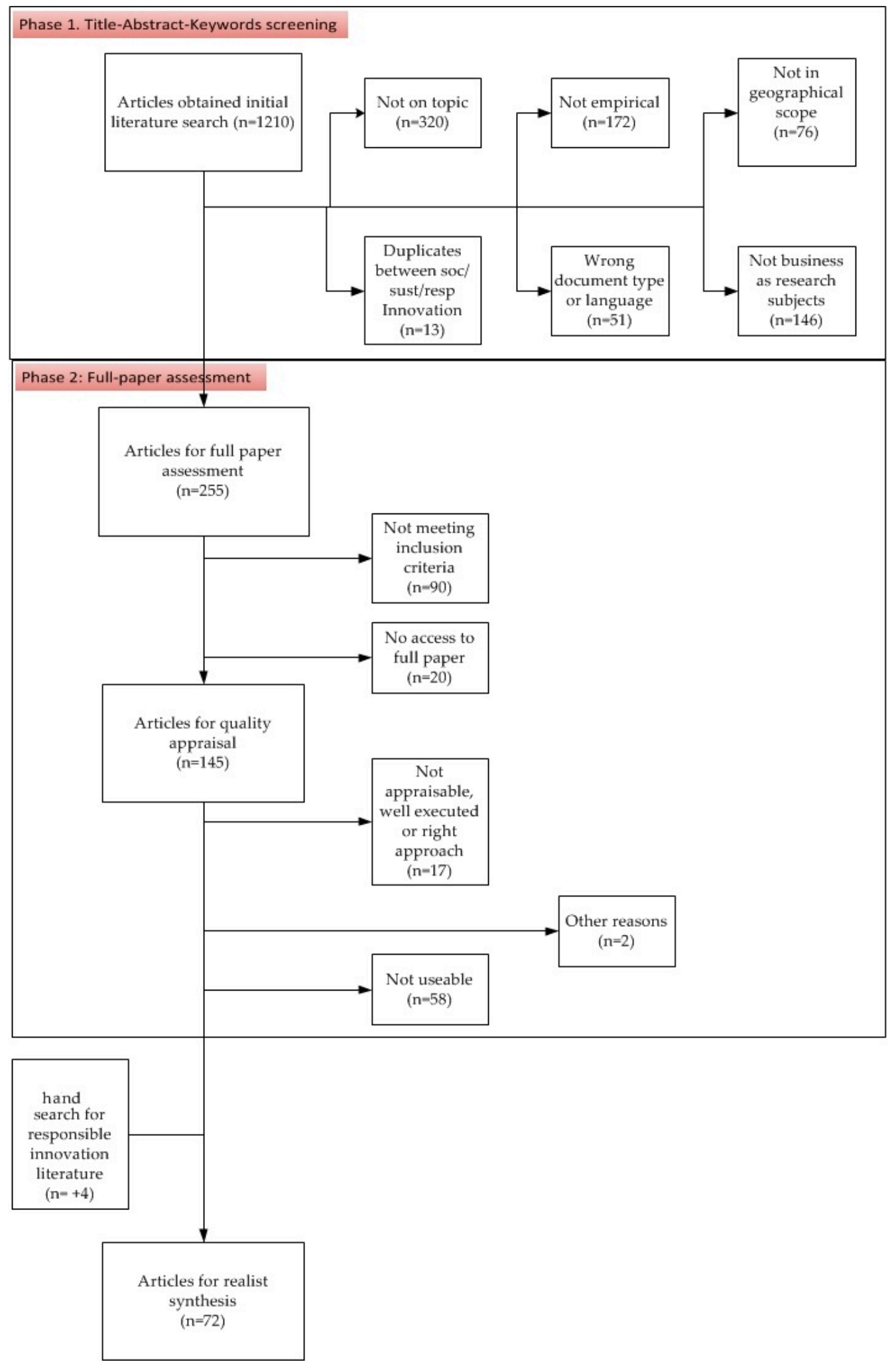

Figure 1. Flow diagram of study selection. 
The fields of responsible, social and sustainable innovation are relatively young. There were 53 articles that were based on case study research, and four articles were the result of mixed-methodology research. Only 15 articles were based on survey data. The fact that most articles were based on case studies indicates that the research in these fields is largely focused on empirical exploration and description. The fact that these fields of research are primarily built on empirical exploration and description indicates that they are still in their infancies [1]. The fact that all included articles (except one) were published from the year 2000 and onwards, with a sharp increase since 2010, supports this.

\section{Stage 3: Framework Synthesis-Final Model of Responsible Innovation in the Business Context}

The dimensions of the current concept of responsible innovation were used as the initial 'architecture' for responsible innovation in the business context. The final model of responsible innovation in the business context is based on deductive and inductive analysis. The latter took place to identify recurring actions that are vital for innovating with society and for society, but are beyond the scope of the initial dimensions. There were multiple knowledge management activities recurring in the articles; activities that were implemented to solve knowledge gaps necessary to develop the innovation (as opposed to socio-ethical considerations). For example, to obtain missing knowledge on the recycling of plastics that is necessary for the desired innovation outcome [40] or to obtain knowledge about biotechnical process engineering for sustainable innovations in the biopolymer industry [41]. There were multiple recurring activities and mechanisms focused on resolving such knowledge gaps, which were therefore coded based on the framework of knowledge management typologies by Denford (2013) [42]. The outline of the results based on our synthesis presents the following dimensions respectively: anticipation, reflexivity, inclusion, deliberation and responsiveness. The results section is expanded by adding an overview of the key activities and mechanisms for the knowledge-based dynamic capability.

\subsection{Anticipation}

There are two important mechanisms that stand out when it comes to anticipating the future implications of the innovation and linking it to current decision-making processes. First of all, organisations engage in multiple activities that enhance their understanding of the innovation context (i.e., societal trends, market trends, technological developments, legislation and regulations) [39,41,43-45]. Second of all, organisations engage in activities that improve their long-term vision and enable them to align it with their decision-making processes for innovation [39,46-48].

Firms implemented several activities to gain a better understanding of the innovation context. They monitored their external environment to identify changes in the innovation context [41] or via activities that helped them to understand the different contextual layers [49]. This is important in trying to understand how the development and implementation of innovation is interrelated with the innovation context $[39,47]$. Scenario methods can help to achieve this $[39,46]$ such as the double-flow scenario method [39] which is beneficial for "understanding the hierarchical irreversible relationships between the environment, society and economy, issues threatening the sustainability of the society and the implications of these on their organization. [And] generating normative long-term visions of sustainable societies and developing scenario maps to identify alternative innovation paths between present and these visions" (p. 114).

In addition to understanding the innovation environment, it is important to understand the social needs or the problem to be addressed. Especially with regard to the social context, organisations aim to interact with people to better understand their needs $[43,45,50]$. However, there is ambiguity in the business context as to whether the firm addresses societal needs and/or (potential) customer needs [43,51]. Some firms visit communities that they aim to serve [43] or develop a platform where members of the public can express their needs or concerns (e.g., a living lab [50]). Subsequently, companies aim to generate innovative ideas that respond to the expressed needs or problems. Traditional ways like 'pen and pencil', brainstorming activities and idea boxes are still used to 
generate innovative ideas [52]. However, there are also examples of multi-stakeholder ideation (e.g., crowdsourcing of focus groups) that are initiated to generate innovative ideas together with the target group or consumers [53-56]. Another innovation that can help to develop innovative ideas is collaborative business modelling [47], which "creates a powerful platform for: (1) jointly identifying economic and societal value; (2) defining value creation/value capture systems; (3) planning of complex and uncertain future markets" (p. 4).

While companies are primarily engaged in thinking about the desirable innovation outcomes, they are also aware of possible unforeseen consequences that come with innovation. They engage in several coping mechanisms implemented to reduce that uncertainty $[41,47,57,58]$. These uncertainties are primarily articulated in terms of innovation rejection, whether sufficient knowledge is at hand to develop the innovation, or other uncertainties that can be linked to business concerns $[57,59]$. Only a few articles reported innovation activities that aimed to reduce the uncertainty that innovation can have negative implications for the innovation environment (e.g., [44]). Organisations adopt different strategies to create (more) predictable conditions for the change that the innovation could bring [57]. There are also companies that adopt strategies to overcome or prevent competency lock-in that is associated with innovation uncertainty [41].

Subsequently, when the interrelationship between the innovation and its environment is clear, it is important that actors develop roadmaps consisting of alternative ways in which the desired impact can be achieved $[39,47,60,61]$. The focus then is on translating organisational vision into innovation requirements, and subsequently day-to-day activities for development $[57,59,62-64]$. Therefore, in the end we can define anticipation as: the act of determining the desired impact(s) and outcomes of the innovation process to address societal and/or environmental needs (1), the negative impacts to be prevented or mitigated (2), and the uncovering of the different pathways through which this can be achieved (3) while being aware of the inevitable uncertainty of forecasting. Table 1 contains an overview of the key activities of anticipation, their strategies, and examples of reviewed papers in which the key activities and strategies are described.

Table 1. Operationalisation of the dimension anticipation.

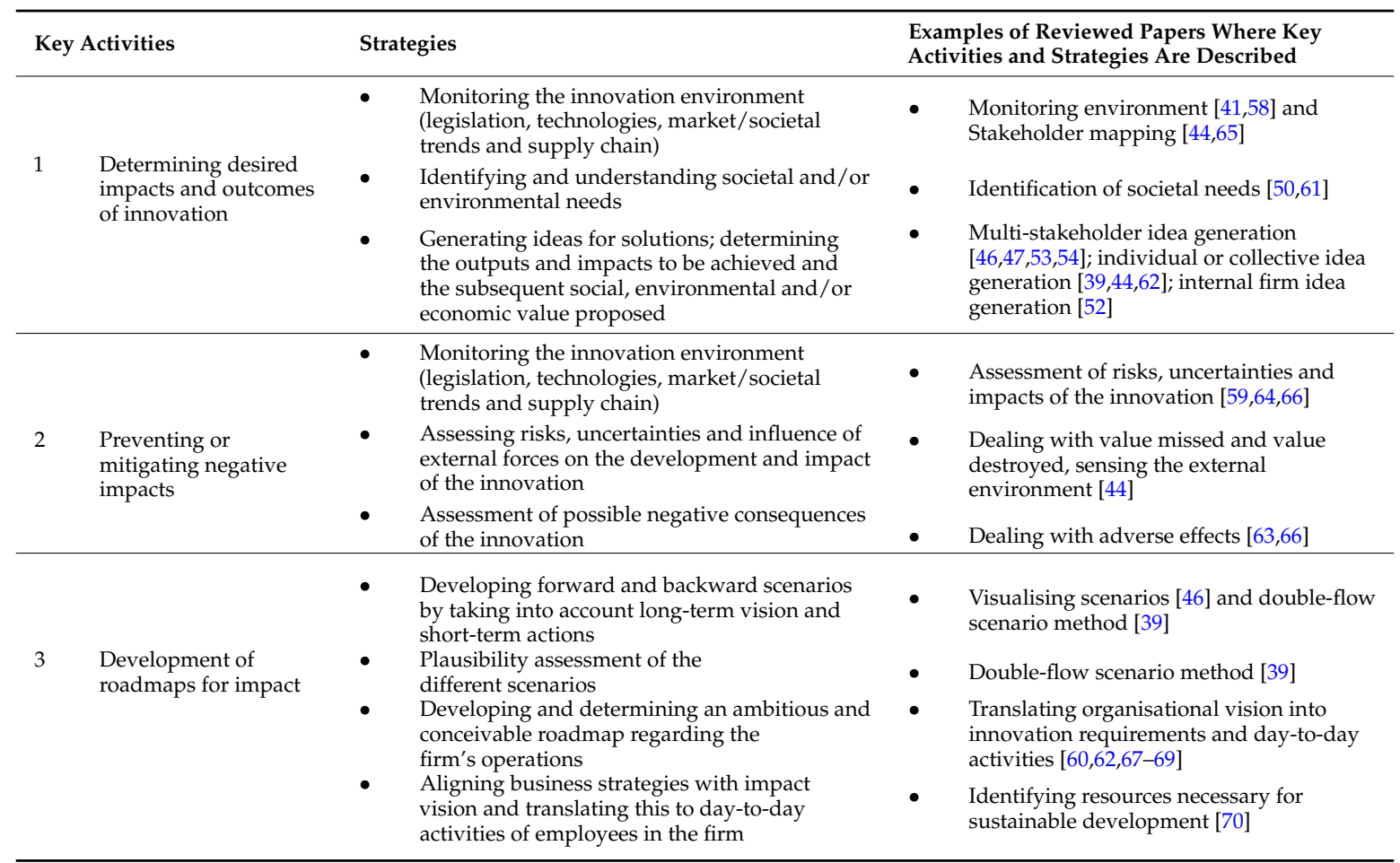




\subsection{Reflexiveness}

Reflexive innovators engage in several elements that need to be managed when engaging in innovation. They evaluate whether current and previous actions support the governance of the innovation process and help to achieve the desired outcomes of the innovation (e.g., [45]). The evaluation of the innovation needs to be in line with the type of innovation, what element is looked at, and the purpose of the innovation $[45,49,57,69]$, for example to prevent illusory validation [62]. Innovators face the risk that they may look at the wrong metrics when evaluating if the innovation has the desired implications. They tend to take for granted that they do good, without looking for further improvement. For example, target beneficiaries can express gratitude, while the innovator should also look at how grateful beneficiaries are and how the innovation can be improved. Also, being in receipt of grants, fellowships or donations does not guarantee that the innovation is actually having the desired impact [62].

Reflexivity can take place in the form of formal evaluations (e.g., whether the performance is in line with the objectives that are set) (e.g., $[45,48,71])$ and can also be achieved by encouraging a self-reflective ethos in the firm [45]. Some articles reported innovation activities that help innovators to reflect on their responsibility to society. This can be done by discussing and articulating the reason for the existence of the firm (and the responsibilities that come with that) or having internal discussions among employees to increase awareness of the influence that their company has on society $[56,65]$. There are also examples of innovators who reflect on their role responsibilities (as opposed to wider moral responsibilities) [69,72].

Innovators can think about the effect of one's own values and motivations on innovation governance and outcomes. Values and motivations are used as heuristics when decisions have to be made under uncertainty or when faced with conflicting options [40]. That is why it is worrying that drivers such as profit or legislation are still the primary motivations when innovating for sustainability [44,52,58,73-75]. Personal ethics appear to be critical for achieving truly sustainable or social innovations when they are compatible with business sensibilities $[52,76,77]$. This is especially true of the personal ethics of the owner/manager, as their values and motivations affect leadership, organisational culture and ultimately the management of the innovation project. Innovators need to be aware that stakeholders can have different values and motivations, as this affects the development of the innovation (e.g., [44]). However, there are still opportunities for innovation when values are conflicting. In those cases, it can be worthwhile to look for compatibility among the values held by different stakeholders instead of aiming for shared values [78,79].

Innovators can think about the presence, absence and subjectivity of information, the knowledge and abilities they possess, the perceived realities, and their subsequent effect on innovation management. Open communication is important to become aware of the subjectivity of knowledge and to reconcile different conceptions of reality (e.g., [45]). Also, activities that encourage reframing of problems and/or solutions, or that encourage involved stakeholders to challenge their own and the firm's approaches, can help the firm to reflect on their thoughts and practices $[68,80]$. This is important, since present knowledge, experiences and routines affect how problems are understood and subsequently affect the search for solutions [52]. It is also important to scrutinize whether the information is complete, objective or accurate $[59,68]$. The reported innovation practices and processes were primarily responding to more (practical) knowledge-related problems around innovation, while there were fewer activities mentioned that responded to moral dilemmas, responsibilities and ethical issues.

Therefore, reflexivity can be defined as: critically thinking about one's own actions and responsibilities (1), values and motivations (2) knowledge and perceived realities (3), and how each of these have an effect on the management of the innovation process for the desired outcome. Table 2 contains an overview of the key activities of reflexiveness, their strategies, and examples of reviewed papers in which the key activities and strategies are described. 
Table 2. Operationalisation of the dimension reflexiveness.

\begin{tabular}{|c|c|c|c|}
\hline \multicolumn{2}{|c|}{ Key Activities } & Strategies & \multirow{2}{*}{$\begin{array}{l}\text { Examples of Reviewed Papers Where Key } \\
\text { Activities and Strategies Are Described } \\
\text { - } \quad \text { Actions and responsibilities }[8,67,69,81]\end{array}$} \\
\hline \multirow{3}{*}{1} & \multirow{3}{*}{ Actions and responsibilities } & $\begin{array}{l}\text { Making sure that there are formal } \\
\text { evaluations, third party critical appraisal } \\
\text { or an informal (self-) assessment culture }\end{array}$ & \\
\hline & & $\begin{array}{l}\text { - Creating a culture where there is } \\
\text { empowerment of employees }\end{array}$ & - $\quad$ Empowerment $[45,78]$ \\
\hline & & $\begin{array}{l}\text { - Becoming aware of the function and } \\
\text { power of the firm in society, and the } \\
\text { responsibility that comes with that }\end{array}$ & - $\quad$ Reflection on responsibilities [56,65] \\
\hline \multirow{3}{*}{2} & \multirow{3}{*}{ Values and motivations } & - $\quad$ Prioritization of values and motivations & Prioritization and conflicts $[44,78]$ \\
\hline & & $\begin{array}{l}\text { Thinking of the effect of one's values on } \\
\text { innovation governance and outcome(s) }\end{array}$ & $\begin{array}{l}\text { - Effect of values and motivations on } \\
\text { innovation governance }[51,52]\end{array}$ \\
\hline & & $\begin{array}{l}\text { Determining how to deal with } \\
\text { incompatible values and/or motivations }\end{array}$ & $\begin{array}{l}\text { Business values and innovation } \\
\text { governance }[56,78,79]\end{array}$ \\
\hline \multirow{4}{*}{3} & \multirow{4}{*}{$\begin{array}{l}\text { Knowledge and } \\
\text { perceived realities }\end{array}$} & $\begin{array}{l}\text { - Scrutinizing the presence, absence and } \\
\text { subjectivity of information }\end{array}$ & $\begin{array}{ll} & \text { Reflecting on and reframing perceived } \\
& \text { realities }[80,82]\end{array}$ \\
\hline & & $\begin{array}{l}\text { - Assessment of the knowledge and } \\
\text { abilities present in the firm }\end{array}$ & $\begin{array}{l}\text { - } \quad \text { Knowledge, Concept, Proposal process } \\
(\mathrm{KCP})[68]\end{array}$ \\
\hline & & $\begin{array}{l}\text { - Becoming aware of different perceived } \\
\text { realities between actors }\end{array}$ & $\begin{array}{l}\text { - } \\
\text { reconcilities [45,83]; encouraging diversity } \\
\text { management for innovation [84] }\end{array}$ \\
\hline & & Reframing of problems and solutions & KCP process [68] \\
\hline
\end{tabular}

\subsection{Inclusion}

Inclusion can be considered as stakeholder engagement, where innovators determine who to involve, how, and during which stages of the innovation process. The goals of innovation networks are more likely to be achieved when a diversity of stakeholders share similar values [56] or when stakeholders are willing to look for compatible values for the overall goal to be achieved [78]. Managing the network is best achieved when it is comprised of actors who together have the organisational, relational and technical capabilities to bring the innovation to a good end [78]. There were few articles that reported organisations who engaged with the general public (e.g., [50,78]). Instead, articles were reporting activities indicating that innovators are primarily engaging with customers and end-users in order to be responsive to their needs $[48,51,85]$. Other stakeholders who were often mentioned are: partners in the supply chain and external knowledge institutes (e.g., universities or research centres). Stakeholders are often involved to resolve knowledge-related problems that come with innovations, which is done by developing the knowledge together or obtaining knowledge from them; for example, collaborating with industry experts in recycling plastics to develop a sustainable product [40]. However, stakeholders were not involved in helping innovators with moral dilemmas or to resolve questions around ethics.

The aim is to achieve and maintain high levels of commitment and involvement by stakeholders [86] is more likely when information is shared between the firm and its stakeholders. Additionally, the distribution of value between stakeholders, the process of determining this distribution of value, and the extent to which stakeholders can identify with the firm leading the innovation affect the eagerness to participate in the network [54]. However, sharing information and maintaining relationships can also be considered as costs for the leading firm. On the one hand, more open innovation processes where innovation is accelerated by the management of inflows and outflows of knowledge (e.g., idea competitions, collaborative R\&D, etc.) can lead to the improvement of the innovation performance. But on the other hand, it can also have negative effects on the competitiveness of the firm $[71,87,88]$. Therefore, instead of sharing all information and being fully transparent, organisations engage in selective openness, with limitations on what information to share, at what point in time and to whom [89]. Another difficulty is the balance between engaging with stakeholders and fostering deliberation while at the same time aiming to maintain the primary power during the innovation process. How this is managed optimally is context-dependent, and therefore 
determined on a case-by-case basis. Balancing costs and benefits of such innovation processes is a learning activity for the firm, as it seems hard to manage this successfully.

Inclusion can therefore be defined as: the involvement of a diversity of stakeholders during different stages of the innovation process (1) who comprise a quality innovation network providing different resources necessary for responsible governance of the innovation process and the achievement of the desired outcomes (2). Raising commitment and contribution by multiple stakeholders benefits network performance and can be achieved by creating and maintaining relationships that satisfy stakeholders (3). Table 3 contains an overview of the key activities of inclusion, their strategies, and examples of reviewed papers in which the key activities and strategies are described.

Table 3. Operationalisation of the dimension inclusion.

\begin{tabular}{|c|c|c|c|}
\hline \multicolumn{2}{|c|}{ Key Activities } & $\begin{array}{l}\text { Strategies } \\
\text { Consult, integrate or collaborate with the: }\end{array}$ & $\begin{array}{l}\text { Examples of Reviewed Papers Where Key Activities and } \\
\text { Strategies Are Described }\end{array}$ \\
\hline \multirow{7}{*}{1} & \multirow{7}{*}{$\begin{array}{l}\text { Involvement of } \\
\text { stakeholders at } \\
\text { different stages } \\
\text { (who and when) }\end{array}$} & - Wider public & $\begin{array}{l}\text { - Living lab inclusion [50]; community involvement } \\
{[43,90,91] \text {; focus group with the wider public [56] }}\end{array}$ \\
\hline & & - Supply-chain actors & $\begin{array}{l}\text { Alliance formation and responsible supply-chain } \\
\text { development }[41,71]\end{array}$ \\
\hline & & - $\quad$ End-users & $\begin{array}{l}\text { Formal role of the end-user in the company and } \\
\text { crowdsourcing }[51,54]\end{array}$ \\
\hline & & - $\quad$ Non-governmental organisations (NGOs) & $\begin{array}{l}\text { - Innovation system with NGOs [78]; creating more } \\
\text { impact with NGOs [79] or social alliance } \\
\text { innovation [92] }\end{array}$ \\
\hline & & - $\quad$ Experts & $\begin{array}{l}\text { Expert involvement for epistemic problems [59]; } \\
\text { external research and evaluation [78]; support of } \\
\text { experts for in-depth anticipation [69,93] or } \\
\text { inclusion for technological problems [72] }\end{array}$ \\
\hline & & - $\quad$ Multiple stakeholders & $\begin{array}{l}\text { - (Multi-)stakeholder involvement } \\
\text { activities }[45,71,84,94]\end{array}$ \\
\hline & & - $\quad$ Governmental agencies & - $\quad$ Role of private firms versus government [95] \\
\hline \multirow{5}{*}{2} & \multirow{5}{*}{$\begin{array}{l}\text { Provision of } \\
\text { resources and } \\
\text { capital (how) }\end{array}$} & $\begin{array}{l}\text { - Consultancy (e.g., scientific support or } \\
\text { governmental support) }\end{array}$ & - $\quad$ Bridging and bonding with experts $[59,76,78]$ \\
\hline & & $\begin{array}{l}\text { User-innovation (e.g., crowdsourcing, } \\
\text { focus groups or bottom-up innovation) }\end{array}$ & $\begin{array}{l}\text { Official role in firm for users and focus group with } \\
\text { wider public [51,56]; crowdsourcing [53,54,89]; } \\
\text { user-driven innovation [91] }\end{array}$ \\
\hline & & - $\quad$ Community visits & 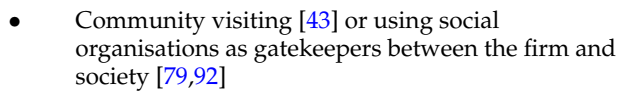 \\
\hline & & $\begin{array}{l}\text { - Indirect representatives (e.g., thought } \\
\text { experiments, role playing or } \\
\text { via intermediaries) }\end{array}$ & $\begin{array}{l}\text { - Representation of stakeholders for } \\
\text { anticipation [44,67] or intermediaries support in } \\
\text { innovation processes [55] }\end{array}$ \\
\hline & & $\begin{array}{l}\text { (Public) platform for expressing needs } \\
\text { and concerns }\end{array}$ & - $\quad$ Living lab [50] \\
\hline \multirow{5}{*}{3} & \multirow{5}{*}{$\begin{array}{l}\text { Raised } \\
\text { commitment and } \\
\text { contribution } \\
\text { (how) }\end{array}$} & $\begin{array}{l}\text { Balancing transparency and openness in } \\
\text { relationships and the innovation process, } \\
\text { and receiving input from external actors }\end{array}$ & - $\quad$ Examples of cost-benefit struggles $[71,87,88]$ \\
\hline & & $\begin{array}{l}\text { - Fair relationships regarding the tasks and } \\
\text { returns for stakeholder input }\end{array}$ & - $\quad$ Creating crowdsourcing satisfaction $[53,54]$ \\
\hline & & $\begin{array}{l}\text { Role recalibrations as roles change over } \\
\text { time and need to be readjusted }\end{array}$ & $\begin{array}{l}\text { Maintaining workable stakeholder relationships } \\
\text { over time [86] }\end{array}$ \\
\hline & & $\begin{array}{l}\text { - Working with actors sharing the } \\
\text { same values }\end{array}$ & - $\quad$ Creating positive ethical networks [56] \\
\hline & & $\begin{array}{l}\text { - Working with actors with different } \\
\text { (sometimes opposing) values }\end{array}$ & $\begin{array}{l}\text { - Strategies to reconcile opposing views [78] or } \\
\text { bridging opposing values and new values } \\
\text { creation [86] }\end{array}$ \\
\hline
\end{tabular}

\subsection{Deliberation}

Multiple studies indicated that companies are engaged in a dialogue with different stakeholders [51]. This is done in different ways, such as crowdsourcing [54,55], focus group discussions [56], workshop settings [47,96], community visits [41,43,91], and deliberation with experts in the field [59].

There are several conditions mentioned in the literature that can improve stakeholder dialogues. Namely, that they are (ideally) based on accurate and transparent information [51,54], constructively work toward common interests [44], show respectfulness to contributors, and are based on trust 
and credibility between contributors $[78,90]$. The exchange of views and opinions was requested in order to evaluate and give meaning to shared information and knowledge, but also to determine the criteria for evaluation $[47,50,78$ ] that can be different among stakeholders (e.g., [55]). Articulating or visualising $[46,91]$ the development of the innovation and the expected outcomes can help to increase understanding among stakeholders.

Deliberation takes place in many cases with customers and end-users $[41,48,51,90]$, but also (professional) communities [45,50,78,79]. Deliberation with the (potential) customers or end-users can help organisations to better understand their needs and how the innovation can be responsive to those needs $[41,51,57,67]$. However, it is also important to deliberate with stakeholders who can contribute to the actual development of the innovation. In these cases, deliberation also serves to enhance understanding about the actions and commitments of each stakeholder for the development of the innovation [96], and how their interests can be aligned with the overall objective of the collaboration $[43,85,92]$.

There are several ways that enable involved stakeholders to influence the decision-making process. Indirectly, they can provide their non-binding view or opinion about the decision to be made [56]; directly, they can participate in the decision-making by means of voting [54,55], or in exceptional cases they may have a place in the organisational structure of the firm [51]. For actors to be satisfied regarding the deliberation, innovators must share what the outcomes of the deliberation are and how contributors' opinions are translated into innovations, or why that was not the case [54].

Therefore, deliberation can be defined as: a commonly agreed two-way exchange of views and opinions between stakeholders (1) based on shared information and evaluation criteria (2) that could support decision-making with regard to the innovation that is under consideration (3). This can be complemented with actual decision-making power of stakeholders regarding the innovation process and/or outcomes (4). Satisfying contributors is achieved by providing feedback regarding the dialogue and explaining how the results are integrated into the innovation (5), which can facilitate innovation adoption. Table 4 contains an overview of the key activities of deliberation, their strategies, and examples of reviewed papers in which the key activities and strategies are described.

Table 4. Operationalisation of the dimension deliberation.

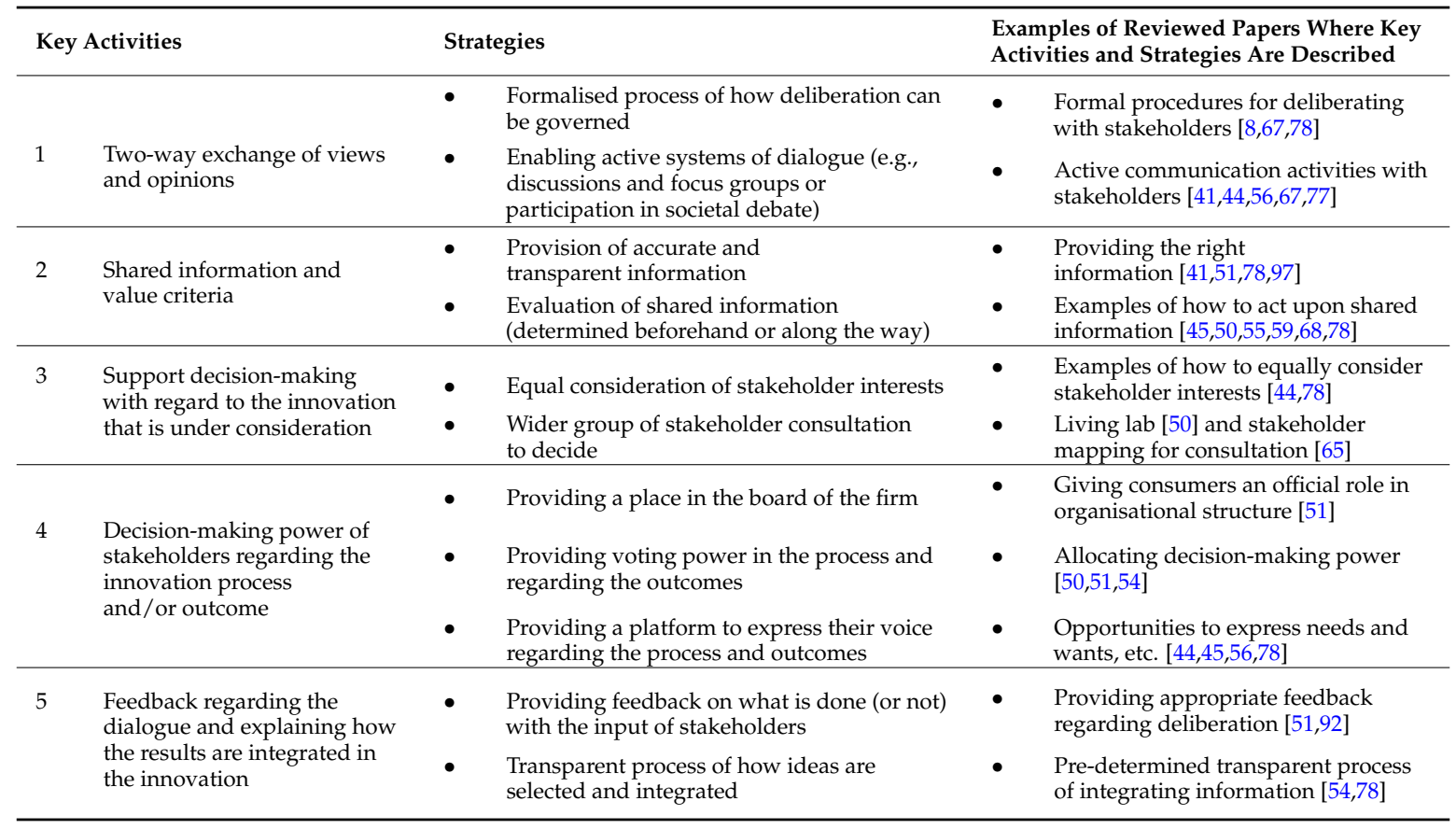




\subsection{Responsiveness}

Companies need to make sure that they are aware of new information about the external environment that would require adjustment of the innovation. Also, new information about the innovation itself could urge innovators to make adjustments. Furthermore, companies need to be able to respond to these changes and new information during and after innovating. In the end, they need to actually adjust the innovation in order to be responsive.

Companies aim to monitor the circumstances in which the innovation is implemented, including after the innovation is launched onto the market. However, deliberation with the aim of understanding the problem addressed or the changing stakeholder needs does not necessarily mean that the innovator is willing, or able, to take responsibility for addressing them with the innovation [8]. It is important that companies do not experience organisational inertia, bureaucracy, or other factors such as resistance to change [43] or a lack of resources [45], which can hinder efficient and effective responsivity [68,77]. Furthermore, small firms can especially experience a lack of resources to adequately respond to reasons for adjusting the innovation. Companies can respond to changes in the external environment by developing responsive innovation strategies $[43,49,57,98]$. An example of this is mainstreaming, which is similar to tailoring the product for local needs [57]. It is clear that more open and adaptive innovation processes are more flexible to being tailored to different local contexts [57,99].

Some companies argue that since one cannot fully anticipate all risks and uncertainties, it is better to develop and launch the innovation and to then make subsequent effective adjustments afterwards (learning-whilst-doing) [62,99]. This enables them to be responsive to feedback from the external environment or to new insights regarding the innovation's impacts $[62,99]$. The changing circumstances to which the company responds can originate from within the firm but also from their external environment [76]. When it is not possible to safeguard the society from detrimental impacts, or the innovation is not ethically acceptable, societally and/or environmentally desirable, the decision needs to be made as to whether the innovation should be launched into the market or taken off the market [59,63,64].

Companies can also benefit from collaboration with other firms or stakeholders, for example to keep up with information flows, changes in the innovation system, and to be able to respond to them $[45,58,77,100]$. In some cases it can be necessary to refine the business model to be successfully responsive to changes in the external environment [100,101]. When developing an innovation with different stakeholders, it is important that there is clarity about the roles and responsibilities of those stakeholders $[69,92]$. Stakeholders can be mutually responsive to each other if they recalibrate the roles they play during the innovation process [86]. Successful innovations are developed with stakeholders who are willing to readjust their roles during the innovation process, and are open to learn as new information becomes available or known $[62,86,92]$. This is more likely to be achieved when stakeholders can identify themselves with the common objective [86] and invest in the innovation by bringing in resources $[79,92]$.

Therefore, responsiveness can be defined as: making sure that the organisation is able to, and actually does, adjust the innovation process in accordance with events and changing circumstances that take place during the innovation process (1) within and outside the organisation (2), in order to safeguard the achievement of the desired innovation outcomes which address grand challenges and/or prevent detrimental effects (3). This can imply that the innovation project will be adjusted or even withdrawn from market launch. Stakeholders can be mutually responsive to each other by recalibrating their roles and responsibilities during the innovation process (4). Table 5 contains an overview of the key activities of responsiveness, their strategies, and examples of reviewed papers in which the key activities and strategies are described. 
Table 5. Operationalisation of the dimension responsiveness.

\begin{tabular}{|c|c|c|c|}
\hline & Activities & Strategies & $\begin{array}{l}\text { Examples of Reviewed Papers Where Key } \\
\text { Activities and Strategies are Described }\end{array}$ \\
\hline 1 & $\begin{array}{l}\text { Making sure that one } \\
\text { can respond to } \\
\text { changes in } \\
\text { the environment }\end{array}$ & 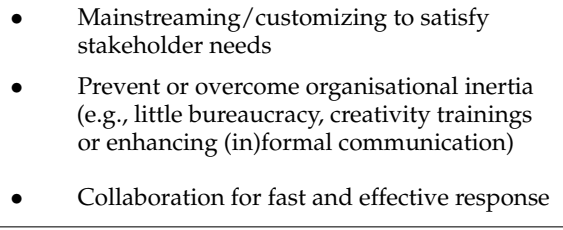 & $\begin{array}{ll} & \text { Customisation activities [57,102] } \\
\text { - } & \text { Autonomous thinking time [45]; } \\
\text { organisational culture for creativity and } \\
\text { innovation [103,104]; KCP process of } \\
\text { reframing problems [68] } \\
\text { - } \quad \begin{array}{l}\text { Absorptive capacity routines combining } \\
\text { user and technical knowledge [45] }\end{array} \\
\end{array}$ \\
\hline 2 & $\begin{array}{l}\text { Actual response to } \\
\text { changing environments }\end{array}$ & $\begin{array}{l}\text { Defining nature, pace and impact based on } \\
\text { interactions with the innovation system } \\
\text { - } \quad \begin{array}{l}\text { Reinventing (innovation and organisation) } \\
\text { to align with newly recognized needs }\end{array} \\
\text { - Changing the environment (e.g., } \\
\text { institutional barriers or } \\
\text { social epistemologies) }\end{array}$ & 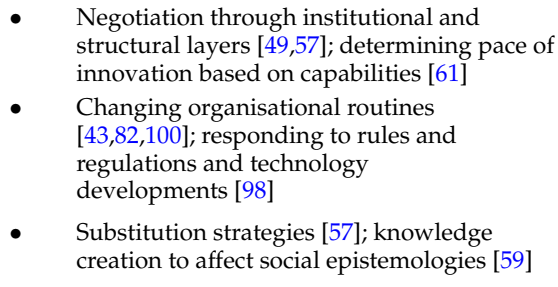 \\
\hline 3 & $\begin{array}{l}\text { Addressing } \\
\text { grand challenges }\end{array}$ & $\begin{array}{l}\text { - } \quad \text { Responding to environmental issues } \\
\text { - } \quad \text { Responding to economic issues } \\
\text { - } \quad \text { Preventing detrimental effects }\end{array}$ & $\begin{array}{l}\text { Examples of articles looking into social } \\
\text { aspects of innovations }[43,49,50,92] \\
\text { Examples looking at responding to } \\
\text { environmental challenges and integrating } \\
\text { environmental goals in innovation } \\
\text { [40,52,61,63,64,95] } \\
\text { Responding to poverty [49]; responsible } \\
\text { financial products [48] } \\
\text { - Consideration of withdrawing innovation } \\
\text { from the market }[59,64]\end{array}$ \\
\hline 4 & Mutual responsiveness & $\begin{array}{l}\text { - } \begin{array}{l}\text { Aligning stakeholder interests with the } \\
\text { overall innovation objective } \\
\text { - } \quad \text { Investment of resources by } \\
\text { involved stakeholders } \\
\text { - Willingness to recalibrate the roles and } \\
\text { responsibilities for sustaining } \\
\text { stakeholder relationships }\end{array} \\
\end{array}$ & 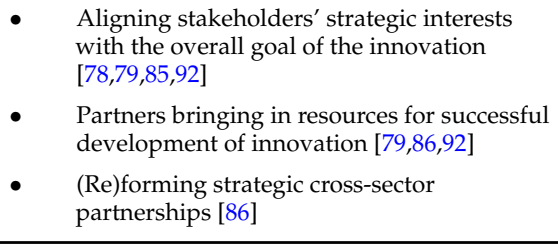 \\
\hline
\end{tabular}

\subsection{Knowledge Management}

The dimension of knowledge management is a recurring theme observed after inductive analysis of the articles. Firms can lack knowledge that is necessary for developing an innovation that is responsive to stakeholder needs. Therefore, they engage in different activities to obtain the necessary knowledge. These activities are coded based on the typologies of knowledge-based dynamic capabilities developed by Denford [42].

The main approaches to obtain the necessary knowledge are to create the knowledge within the firm (e.g., by experimenting) and to integrate present knowledge throughout other parts of the firm. However, there are also activities that lead to the development of the necessary knowledge with actors or organisations beyond the firm, obtaining the knowledge from them, and/or synthesising knowledge.

Firms aim to solve the knowledge gaps by themselves, obtaining the missing knowledge without the involvement of external actors. For example, this can be done by engaging in knowledge creation, which takes place within the firm and is focused more on the exploration of new knowledge. Examples of this are: different units in the firm that learn from each other, and those that engage in experimenting or other ways of creating, searching for, and combining intra-firm knowledge [46,52]. This requires a culture of innovation, learning-by-doing, experimentation and Research and Development (R\&D) [73]. Firms also engage in knowledge integration, which is about generating new innovations with already present knowledge, resulting from internal knowledge transfer between departments and multidisciplinary groups for innovation $[41,45,51,52,61,99]$. For example, this can be achieved by having internal platforms and networks within (especially large) firms that enable the flow of knowledge between departments [51,60].

Firms also aim to solve knowledge gaps by developing missing knowledge with other firms, or absorbing the knowledge of other firms. Firms engage in knowledge development with 
other actors, where together they obtain new knowledge $[40,41,47,59,90]$, for example by joint R\&D agreements [41,105]. Firms can also absorb external knowledge to bring it within their own firm, for example by bringing in extant knowledge by partnerships or communicating with stakeholders who have creative and/or practical knowledge $[41,43,51,52,68,72,87,106]$. Firms engaging in knowledge synthesis can also develop better innovations when combining external knowledge and exploiting this by combining it with knowledge already present within the firm [51]. Examples of this are: collaboration partnerships and information exchanges between firms and external actors $[45,59,60,79,90,93,106]$.

Therefore, knowledge management can be defined as: creating or obtaining knowledge to solve knowledge gaps that come with the processes and outcomes of the innovation (1), in order to subsequently integrate it into the innovation process (2). Table 6 contains an overview of the key activities of knowledge management, their strategies, and examples of reviewed papers in which the key activities and strategies are described.

Table 6. Operationalisation of the dimension knowledge management.

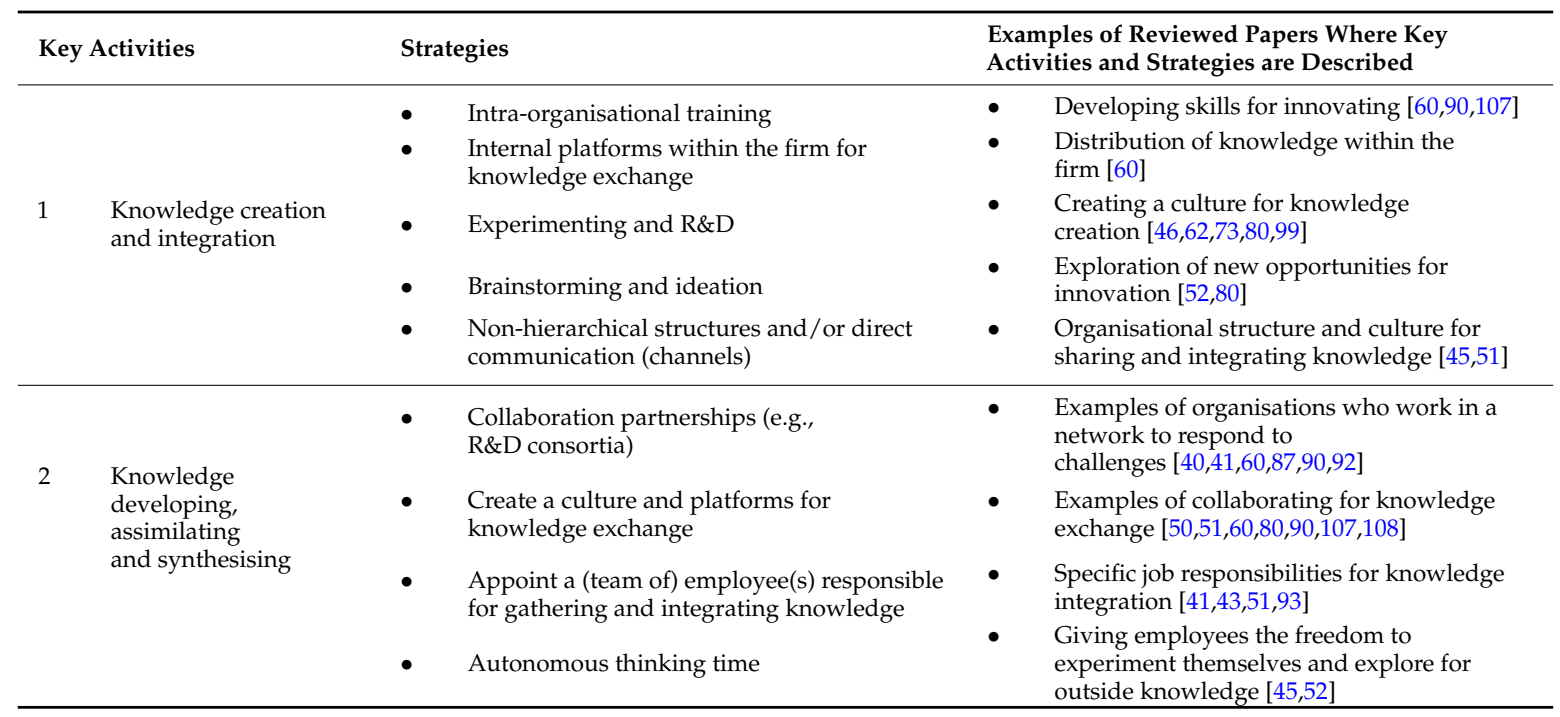

\section{Discussion}

The aim of this review is to explore how companies can engage in responsible innovation practices. The focus was to review practices that can constitute day-to-day responsible innovation activities of companies who want to develop innovations that respond to grand societal challenges. However, there are a few limitations that need to be taken into account when interpreting the results of this review. First, research on responsible innovation and the initial framework of responsible innovation proposed by Stilgoe et al. [3] are predominantly influenced by a European discourse. However, responsible innovation should 'not seek to impose an a priori framework' for contexts beyond the European one [7]. Therefore, we stress that any responsible innovation framework should be critically assessed before being implemented in a particular innovation context, especially for innovation contexts beyond the European borders. Second, the refined framework of responsible innovation that we propose in this review can be seen as a bricolage of innovation activities coming from responsible, social and sustainable innovation articles. Even though social and sustainable innovation are similar to responsible innovation, differences can be found [18]. Therefore, further research is needed to test how these dimensions can all be applied together in the business context, since there are also most certainly interaction effects between the dimensions. Third, this review investigated what innovation activities are already implemented in the business context that indicate implementation of the dimensions of responsible innovation. This means that the 'initial architecture of responsible innovation' that served as a specific lens for the review is likely to be different from the research lens of the scientists of the 
reviewed articles. We can therefore not rule out that there were non-reported findings beyond the scope of their articles, which could have been of interest for this particular review. Since a systematic literature review is time-consuming, there is an inherent timespan between the search for literature, appraisal of the literature, and publication of the review. As a coping strategy, we conducted a non-systematic literature search to identify and discuss the most recent empirical investigations of responsible innovation in the business context. Literature reviews of responsible innovation $[5,11]$ were consulted, including a non-systematic search in search engines and several reports of European projects investigating responsible innovation.

Again, we found that there are few scholars who empirically investigated responsible innovation practices and processes in commercial R\&D settings. With regard to enhancing anticipation, Arentshorst et al. state that scientists and technology developers should not only engage in constructive technology assessment but also in 'vision assessment' that aims to make the guiding visions, which act as the driving forces behind expectations and promises, more explicit and assessed on their realistic value [109]. With regard to enhancing reflexivity, Flipse et al. proposed that researchers with industrial motivations get in contact with humanists during the early stages of innovation to increase the researchers' awareness of social and ethical considerations in their work [110]. Foley et al. proposed a new refined framework for responsible innovation that builds on the procedural dimensions of Stilgoe et al. and the substantive approach by von Schomberg, including the idea of intraand inter-generational justice [111]. When applied in a case study, they found that their framework is particularly helpful for assessing stakeholders' perceptions regarding responsibilities for innovation. Also, corporate responsibility tools (e.g., International Organization for Standardization (ISO) or Eco-Management and Audit Scheme (EMAS) standards) are proposed to aid the implementation of multiple responsible innovation dimensions, which can help to meet the normative anchor-points that ensue from the European Treaty [112].

There have been several reports published that resulted from research projects on responsible innovation commissioned by the European Union. For instance, the Res-AGorA project was commissioned, in which a "responsibility navigator" is developed [113] that functions as a thinking tool to enhance reflexive processes with the inclusion of stakeholders and policy makers to make research and innovation more responsible, responsive, and sustainable. They propose ten governance principles and requirements to make responsibility an institutionalised ambition within research and innovation. Another project is RRI-Tools [114], where an online tool is co-constructed to make a wide variety of stakeholders familiar with responsible innovation (e.g., research communities, R\&D intensive businesses and citizens). It includes, for example, a self-reflection tool to self-assess one's responsible innovation practices, stimulates learning for more responsible innovation practices, and suggests trainings and further communication. The project Responsible Industry proposes a framework [115] that consists of strategic options and recommendations for more responsible practices and behaviours, which aims to inform CEOs, senior executives and project managers. It addresses questions regarding the roles and responsibilities for implementing responsible innovation in the firm. It also provides methods on how responsible innovation can be integrated along the value chain or how organisations can perform ethical and social impact analyses, among other things.

Our systematic review of the empirical literature reaffirmed that documentation of responsible innovation in the business context is still scarce. Therefore, articles investigating social and sustainable innovation in the business context are included as well. The research in these three related fields were widely distributed and focused on empirical exploratory and descriptive research. Furthermore, systematic literature reviews for each of these concepts state that consensus on the definition and conceptualisation of these concepts is lacking. Supported by the fact that most of the included studies are published after 2010, we argue that research in this field in general, and responsible innovation in particular, are primarily in the phase of theory-building. This study aims to not only focus on theory-building, but also to provide practical substance to the initial framework introduced by Stilgoe et al. to inform practitioners who would like to engage in responsible innovation. 


\section{Conclusions}

In order to move the field of responsible innovation forward, it is important to investigate how de facto responsible innovation can be successfully implemented in the private sector in the current political and socioeconomic system. We therefore reviewed effective innovation activities that could help to achieve implementation of the dimensions of responsible innovation in the business context. This review builds on an existing, and gradually increasing, stream of research on responsible innovation. It can be seen as a first effort to support operationalising of responsible innovation in a business context based on insights from a systematic review of approaches from aligned concepts relating to social and sustainable innovation. The results of this systematic literature review can therefore inform future research to assess to what extent companies implemented responsible innovation dimensions during innovation.

The literature on responsible innovation suggests that anticipation involves systems-thinking about the implications of the innovation, including the dynamic interrelationships between the innovation and the system in which it is developed and implemented. While Stilgoe et al. proposed to focus on the underlying purposes of the innovation and discussing desirable implications with stakeholders, there are also voices arguing that negative implications need to be explicitly taken into account. Based on the review of the included articles, we argue that companies are already engaging in systems-thinking for innovation. Furthermore, companies are engaged in understanding the needs of the target beneficiary (often the consumer) and discussing with stakeholders how their innovation can be responsive to their needs. However, innovation activities that critically examine which desirable implications are missed by the innovation, or whether it actually has negative implications [44] were scarce. Therefore, the following research questions for further research are proposed:

- How can innovators in the business context be encouraged so that they are more inclined to foresee possible detrimental implications of the innovations they intend to develop?

- What tools, activities or strategies can be used to help organisations to foresee possible detrimental implications, without holding back potentially desirable innovations?

The literature on responsible innovation suggests that reflexivity is about holding up a mirror to one's own activities, commitments and assumptions. It aims to increase awareness about the limits of knowledge and that one's perceived reality might not be universally held. Additionally, it is important to engage in second-order reflexivity where one thinks about how one's underlying values systems and beliefs influence the development of the innovation, as well as what the role of the organisation and its innovation are in the wider political and socioeconomic system. In the end, innovators should not only live up to their role responsibility but also their wider moral responsibilities [3,24]. The review of the included articles revealed that organisations engage in several activities to reflect on one's own actions, commitments and assumptions. Furthermore, companies are aware of their knowledge gaps and how to address them. While companies do monitor and evaluate their innovations, there is limited evidence that they engage in second-order reflexivity (e.g., [48]). This is an important observation given that their value systems have major implications for the development of the innovation and its future impact (e.g., [49,77]). Therefore, the following research question for further research is proposed:

- How can second-order reflexivity be instilled in innovative organisations in the business context (i.e., reflecting how the underlying value systems and beliefs affect the development and implementation of the innovation)?

The literature on responsible innovation suggests that inclusion and deliberation are about the upstream engagement of stakeholders and the wider public to open up discussions and to interrogate the social, political and ethical implications that the development of the innovation would bring [3]. It involves an "active engagement of stakeholders for the purpose of substantively better decision-making and mutual learning" [23]. Furthermore, stakeholder inclusion and stakeholder deliberation are used interchangeably in responsible innovation literature. 
The findings from the review indicate that stakeholder inclusion was one of the most encountered dimensions of responsible innovation in the reviewed articles. This revolves predominantly around stakeholders such as clients and end-users, and people or organisations with professional expertise. However, the inclusion of the wider public was less encountered, which is unfortunate as the latter can challenge the professional identity of actors engaged in innovation. This is important, as it can urge innovators to reflect not only on what 'innovation excellence' is, but also on macro questions considering the role they and their innovation play in the political and socioeconomic system, and the responsibility that comes with that $[48,116]$.

Supported with the findings from the review of the articles, we still deem it legitimate to differentiate between stakeholder inclusion and stakeholder deliberation. While the two are interrelated, one cannot engage in stakeholder deliberation without inclusion, they do involve different activities. Inclusion focuses more on stakeholder engagement (i.e., which stakeholders to involve and when to involve them), whereas deliberation in the business context is about creating the right conditions for an open and honest dialogue, which should result in better decision-making during innovation.

Most of the empirical studies investigating stakeholder inclusion provided evidence that organisations primarily involve stakeholders who share similar values or stakeholders who are motivated to align their interests with a shared objective of the innovation. However, there were only few reported events where stakeholders with conflicting values, or stakeholders who might oppose the innovation, were involved in the innovation. Therefore, the following research questions for further research are proposed:

- How can stakeholders with dissimilar values, or stakeholders who oppose the innovation, be involved during the innovation process?

- Hence, how does the inclusion of these stakeholders influence the development of the innovation and its subsequent implementation?

The included articles provided evidence that organisations aim to deliberate with stakeholders to improve the decisions made during the development of the innovation. While these efforts can be praised, it is also important that companies consider the costs of these activities. For example, they need to consider what they do with the input from stakeholders, and communicate how stakeholder input influenced the innovation. Furthermore, stakeholders are more willing to engage in deliberation when organisations are more transparent. However, this is not always possible during the innovation process. Firms therefore need to learn how to integrate ethics values in innovation (e.g., by deliberating not only with stakeholders but also the wider public) without putting the survival of the firm at risk. If they manage to do so, a next step would be to institutionalise this within the organisation and to make it a new organisational capability [116,117]. Therefore, the following question for further research is proposed:

- How can organisations engage in an honest dialogue, based on transparent information accessible to the stakeholders involved, without putting their competitive advantage at risk?

Responsiveness is about having the capacity to change the shape or direction of the innovation in response to values of stakeholders and the wider public. Furthermore, it requires a collective institutionalised response and co-responsibility for the responsible development of the innovation [6] in light of new knowledge, perspectives, views and norms that emerge during innovating. The review of the included studies indicates that companies think about how to adjust their innovation to align it with (possible) changes in their external environment. Furthermore, we see that companies collaborate especially with partner firms to develop innovations. These firms recalibrate their roles during the innovation to maintain workable relationships. However, when it comes to mutual responsiveness between people from the industry and other stakeholders, Haen et al. [96] found that both are not necessarily willing to take the responsibility for solving a problem, even after deliberation helped 
them to understand the problem and to find possible solutions. Along the same line, Blok et al. [85] found that not only the company but also the stakeholders are unwilling to be co-responsible for the innovation. When it comes to responsiveness, following the findings by Haen et al. [96] and Blok et al. [85] in that order, the following questions can be raised:

- How can deliberation with stakeholders lead to higher mutual responsiveness of stakeholders involved?

- How can stakeholders involved be held (co-)responsible for the final innovation?

- How can stakeholders be convinced to take part of the responsibility for the development of the innovation?

An important dimension was observed after an inductive investigation of the empirical articles. The activities that were often recurring in the findings of the empirical papers indicated the importance of 'knowledge management' when innovating for society and with society. These activities specifically focus on practical knowledge gaps that innovators face with regard to the development and subsequent impact of the innovation. Organisations subsequently created new knowledge 'in-house' and disseminated this throughout their firm, or they looked beyond their walls and involved other organisations to develop knowledge or share knowledge and insights with them. The latter was especially the case with small and medium size enterprises, which have fewer resources to invest in $R \& D$ to solve the knowledge gaps. Another strategy to deal with this challenge was the monitoring of innovative developments in the external environment. The concept of 'open innovation' can be informative for the dimension of knowledge management because it revolves around internal and external knowledge flows to accelerate internal innovation, and relates to how firms can use both internal and external ideas to advance their innovation. Furthermore, there is more documentation at hand regarding open innovation in the business context, as it has already received significant attention of the academic community. Therefore, not only social-and sustainable innovation but also open innovation can serve as an interesting avenue for future research on responsible innovation.

This review proposes an adjusted framework to examine the activities for responsible innovation in the business context. The main purpose of this framework is to inform how innovators can engage in activities that enhance anticipation, reflexivity, inclusion and deliberation, responsiveness and knowledge management. Besides intra-firm activities, there are also collaborative activities proposed that can enhance the implementation of each of these dimensions. The collaborative activities correspond more with the democratic governance of innovation that is proposed in responsible innovation literature. This adjusted framework for responsible innovation in the business context builds on previous works in the field of responsible innovation. With evidence coming from a diverse body of literature, it gives practical substance to the initial framework proposed by Stilgoe et al. [3].

Even though it goes beyond the purpose of this review, we do touch upon the mutual relationship between responsible innovation and the current political and socioeconomic system. On the one hand, new knowledge and technology embeds and enacts value-laden and politically significant judgments of what the world should look like and will look like [5]. A similar assertion can be said for the concept of responsible innovation, because its proponents have a normative-political orientation as they aim to change the governance of science and innovation, and ultimately change the current political and socioeconomic system [27]. This also holds for alternative approaches to innovation that are currently emerging. For example, there is a growing scientific community in business studies that is investigating social entrepreneurship. Social entrepreneurship and social innovation are anything but value-free, and have politically significant judgments of what the world should look like, and the role that innovation plays in this. Following from responsible innovation, one would suggest that in these alternative approaches to innovation, stakeholders should also be able to negotiate the terms of their inclusion and deliberation, including the politics behind these novel systems, and the substantive biases that can exist. For example, social entrepreneurs risk to let their social concerns outweigh ethical concerns [118] but the input of stakeholders may help to counteract this tendency. 
There are also novel approaches when it comes to innovating for sustainability. The circular economy seems to gain a foothold as a new approach that guides the search for innovative solutions for sustainability. Also, social movements for grassroots innovation are emerging, who encourage community-led innovations for sustainability. On the other hand, proponents of frugal innovation view that the complexity and costs of a product and its production need to be reduced to make it more durable and affordable in developing countries. Then there are also social movements inspired by anti-consumerism and anti-capitalism who promote the pursuit of 'de-growth'. Furthermore, the question can also be raised as to whether to innovate at all. Since each of these approaches to innovation has a view of what the world should look like and the role that innovation plays in this, we argue that the upstream inclusion of stakeholders and the wider public, who deliberate about the innovation at stake, can help to steer these innovation processes and outcomes to ultimately achieve more sustainable, societally desirable and ethically acceptable solutions.

The conclusion can be drawn that responsible innovation does not only ask for new corporate practice in terms of innovation activities, but it also demands that companies reflect on their business models, leadership, and their roles and responsibilities for the political and socioeconomic system in which they operate. The results of this review can help practitioners in the business context to engage in more responsible innovation activities, given the current political and socioeconomic system. It is also informative for policy makers and scientists interested in responsible innovation, as this review serves as a first attempt to move the discussion of 'what responsible innovation means' towards 'how it could be implemented in the business context'.

Supplementary Materials: The supplementary materials are available online at http:/ /www.mdpi.com/20711050/9/5/721/s1.

Acknowledgments: This work is supported by Climate-KiC, which is one of three Knowledge and Innovation Communities (KICs) created in 2010 by the European Institute of Innovation and Technology (EIT). The EIT is a European Union body whose mission is to create sustainable growth.

Author Contributions: Rob Lubberink is the leading author of this study. Vincent Blok contributed significantly to the study design, the conceptual analysis for the initial framework used in this review, the synthesis of the results and final writing of the review. Johan van Ophem was predominantly involved in the study design, and the screening and appraisal of the articles. Onno Omta was involved in the overall supervision of the systematic literature review. All authors read carefully and approved the final version of the manuscript.

Conflicts of Interest: The authors declare no conflict of interest. 


\section{Appendix A}

\begin{tabular}{|c|c|c|c|c|c|c|}
\hline $\begin{array}{l}\text { business } \\
\text { context }\end{array}$ & & responsible & & innovation & & $\begin{array}{l}\text { innovation or business context } \\
\text { related words in title }\end{array}$ \\
\hline \begin{tabular}{l|} 
business* \\
corporat* \\
factory \\
factories \\
workfloor? \\
firm? \\
partnership? \\
ventur* \\
establishment? \\
compan* \\
enterpris* \\
conglomerat* \\
sme* \\
multinational?
\end{tabular} & $A N D$ & \begin{tabular}{|l|} 
responsib* \\
rightful* \\
ethic*
\end{tabular} & $\begin{array}{l}\text { within } \\
\text { three } \\
\text { words } \\
\text { of: }\end{array}$ & \begin{tabular}{|l} 
innovati* \\
progress \\
advancemen \\
enhancemen \\
solution? \\
improvemen \\
novelt* \\
modification? \\
alteration? \\
newness
\end{tabular} & \begin{tabular}{|l} 
AND \\
TITLE \\
CONTAINS \\
ANY \\
OF \\
THE \\
WORDS
\end{tabular} & $\begin{array}{l}\text { innovati* OR progress OR multinationals } \\
\text { OR advancement? OR advance? } \\
\text { OR solution? OR improvement? OR change? } \\
\text { OR novelt* OR modification? OR alteration? } \\
\text { OR newness OR business* OR corporat* } \\
\text { OR factory OR factories OR workfloo* } \\
\text { OR firm OR firms OR organization } \\
\text { OR partnership OR partnerships OR venture } \\
\text { OR ventures OR concern OR concerns } \\
\text { OR establishment OR establishments } \\
\text { OR companies OR enterprise OR enterprises } \\
\text { OR conglomerate OR conglomerates OR sme } \\
\text { OR smes OR multinational } \\
\text { OR enhancement? OR company }\end{array}$ \\
\hline
\end{tabular}

Figure A1. Representation of the search string for a systematic search for responsible innovation studies. The asterisk $\left({ }^{*}\right)$ substitutes zero or more characters, and the question mark (?) substitutes only one character. 
Table A1. Overview of the conceptual overlap and the differences between responsible, social and sustainable innovation.

\begin{tabular}{|c|c|c|c|}
\hline & Responsible Innovation & Social Innovation & Sustainable Innovation \\
\hline $\begin{array}{l}\text { Input for } \\
\text { innovation }\end{array}$ & $\begin{array}{l}\text { The grand challenges }[11,23,119] \\
\text { The uncertainty regarding innovations' future impacts }[3] \\
\text { The embedding of innovation in society }[5,119]\end{array}$ & $\begin{array}{l}\text { The social needs and problems that are not being met by } \\
\text { the government or market actors }[16,120]\end{array}$ & $\begin{array}{l}\text { The climate-related grand challenges [121] that are often } \\
\text { complex [1] } \\
\text { The business opportunity to increase profits by developing a } \\
\text { sustainable innovation }[1,32,33]\end{array}$ \\
\hline \multirow{7}{*}{$\begin{array}{l}\text { Throughput of } \\
\text { innovation (i.e., } \\
\text { the process) }\end{array}$} & $\begin{array}{l}\text { Taking into account innovations' implications and assessing } \\
\text { alternatives [23] }\end{array}$ & $\begin{array}{l}\text { Collectively defining the problem and searching for } \\
\text { solutions [122] and understanding the implications of } \\
\text { social innovations [123] }\end{array}$ & $\begin{array}{l}\text { Comparing different innovations' impacts based on full life-cycle } \\
\text { assessments [32] and engaging in scenario thinking [1] }\end{array}$ \\
\hline & $\begin{array}{l}\text { Reflecting on the effect of the underlying norms, values and } \\
\text { beliefs on the innovation at stake [3] } \\
\text { Deliberating with stakeholders about the underlying norms and } \\
\text { values that should guide the innovation in the desirable direction } \\
\text { Employing normative anchor points of the European Treaty, that } \\
\text { are used as normative goals for Responsible Innovation }\end{array}$ & $\begin{array}{l}\text { Deliberating by consulting whether the needs of target } \\
\text { beneficiaries are met } \\
\text { Assuming that values such as social equality and } \\
\text { sustainability are desirable and translating them into } \\
\text { innovation requirements }\end{array}$ & $\begin{array}{l}\text { Deliberating with stakeholders how the firm and its innovations } \\
\text { can help to achieve system transformation for desirable futures [1] } \\
\text { Reducing the environmental harm per unit (lower level) } \\
\text { Including the social dimension in sustainability next to } \\
\text { environmental and economic dimensions (medium level) } \\
\text { Deliberating with stakeholders about what desirable futures are } \\
\text { and what role the firm and innovation could play (high level) [1] }\end{array}$ \\
\hline & Reflecting on activities, commitments and assumptions [3] & $\begin{array}{l}\text { Reflecting on the social impact and setting of new } \\
\text { goals [122] }\end{array}$ & $\begin{array}{l}\text { Assessing the impact of the innovation over its full life-cycle [32] } \\
\text { and the disclosure of its sustainability performance [1] }\end{array}$ \\
\hline & $\begin{array}{l}\text { Reflecting on wider moral responsibilities next to role } \\
\text { responsibilities [3] }\end{array}$ & $\begin{array}{l}\text { Taking responsibility to solve societal needs and } \\
\text { problems that others do not address [16] }\end{array}$ & $\begin{array}{l}\text { Reframing the purpose of the firm from being apart from society } \\
\text { to being part of society (high level) [1] }\end{array}$ \\
\hline & $\begin{array}{l}\text { Involving and deliberating with relevant stakeholders throughout } \\
\text { a transparent innovation process [9] to make better decisions and } \\
\text { learn from each other [23] }\end{array}$ & $\begin{array}{l}\text { Including stakeholders (primarily target beneficiaries) } \\
\text { for better understanding of the addressed social need or } \\
\text { problem }[16,123]\end{array}$ & $\begin{array}{l}\text { Including stakeholders to increase the knowledge base of the firm, } \\
\text { to improve search activities, to enhance social legitimacy, and to } \\
\text { develop responsive solutions [1]; helping to enhance mutual } \\
\text { learning [124] and improve decision-making [77] }\end{array}$ \\
\hline & $\begin{array}{l}\text { Engaging with stakeholders in general and members of the public } \\
\text { in particular }[3,10]\end{array}$ & $\begin{array}{l}\text { Deliberating with stakeholders in general and the target } \\
\text { beneficiaries in particular }[16,122,123]\end{array}$ & $\begin{array}{l}\text { Engaging with supply-chain partners [lower level]; engaging with } \\
\text { stakeholders that represent the innovation system during the } \\
\text { earliest stages of the innovation process [higher level] Members of } \\
\text { the public are seldom involved to enhance foresight [1] }\end{array}$ \\
\hline & $\begin{array}{l}\text { Acting and adapting to the results from stakeholder inclusion and } \\
\text { deliberation [23] }\end{array}$ & $\begin{array}{l}\text { Generating, selecting and implementing innovative } \\
\text { ideas with other actors to meet social challenges [125] } \\
\text { Less formalised innovations are developed and adjusted } \\
\text { according to the innovation context and needs of target } \\
\text { beneficiaries [16] }\end{array}$ & $\begin{array}{l}\text { Realising mutual responsiveness among supply chain actors } \\
\text { [lower level] } \\
\text { Realising responsiveness by developing an innovation agenda } \\
\text { that responds to the desirable futures projected by involved } \\
\text { stakeholders [higher level] [1] }\end{array}$ \\
\hline \multirow[b]{2}{*}{$\begin{array}{l}\text { Output for } \\
\text { innovation }\end{array}$} & $\begin{array}{l}\text { Innovations that are societally desirable, sustainable and ethically } \\
\text { acceptable [119] }\end{array}$ & $\begin{array}{l}\text { Innovations that enhance social and/or environmental } \\
\text { well-being }[16,123] \text {. }\end{array}$ & $\begin{array}{l}\text { Innovations with reduced environmental impact on society, } \\
\text { preferably none [32,126], that balance social, environmental and } \\
\text { economic considerations. }\end{array}$ \\
\hline & $\begin{array}{l}\text { Predominantly new and emerging sciences and technologies } \\
\text { Along a formalisation continuum from tangible (e.g., drones) } \\
\text { towards intangible (e.g., financial products, Genetically Modified } \\
\text { Organisms (GMOs), etc.) }\end{array}$ & $\begin{array}{l}\text { Innovations that induce the social change necessary for } \\
\text { addressing the societal need or problem [16] that are } \\
\text { already implemented in practice [30] } \\
\text { Social innovations can be found along a continuum of } \\
\text { specificity of the innovation's properties } \\
\text { and characteristics }\end{array}$ & $\begin{array}{l}\text { Sustainable innovation goes beyond technological solutions and } \\
\text { increasingly involves services, business-model and organisational } \\
\text { innovation }[1,127] \\
\text { Not only technology-based innovations but also other } \\
\text { innovations; sometimes sustainable innovation consists of a set of } \\
\text { interrelated innovations [1] that shift a system onto a more } \\
\text { sustainable path [128] }\end{array}$ \\
\hline
\end{tabular}




\section{References}

1. Adams, R.; Jeanrenaud, S.; Bessant, J.; Denyer, D.; Overy, P. Sustainability-oriented Innovation: A Systematic Review. Int. J. Manag. Rev. 2016, 18, 180-205. [CrossRef]

2. Godin, B. Innovation Contested: The Idea of Innovation Over the Centuries; Routledge: New York, NY, USA, 2015.

3. Stilgoe, J.; Owen, R.; Macnaghten, P. Developing a framework for responsible innovation. Res. Policy 2013, 42, 1568-1580. [CrossRef]

4. Sutcliffe, H. A report on Responsible Research and Innovation; MATTER: London, UK, 2011.

5. Ribeiro, B.E.; Smith, R.D.J.; Millar, K. A Mobilising Concept? Unpacking Academic Representations of Responsible Research and Innovation. Sci. Eng. Ethics 2016, 23, 81-103. [CrossRef] [PubMed]

6. Owen, R.; Stilgoe, J.; Macnaghten, P.; Gorman, M.; Fisher, E.; Guston, D.H. A Framework for Responsible Innovation. In Responsible Innovation: Managing the Responsible Emergence of Science and Innovation in Society; Owen, R., Bessant, J., Heintz, M., Eds.; John Wiley and Sons, Ltd.: Chichester, UK, 2013; pp. 27-50.

7. Macnaghten, P.; Owen, R.; Stilgoe, J.; Wynne, B.; Azevedo, A.; de Campos, A.; Chilvers, J.; Dagnino, R.; di Giulio, G.; Frow, E.; et al. Responsible innovation across borders: Tensions, paradoxes and possibilities. J. Responsible Innov. 2014, 1, 191-199. [CrossRef]

8. Armstrong, M.; Cornut, G.; Delacôte, S.; Lenglet, M.; Millo, Y.; Muniesa, F.; Pointier, A.; Tadjeddine, Y. Towards a practical approach to responsible innovation in finance: New Product Committees revisited. J. Financ. Regul. Compliance 2012, 20,147-168. [CrossRef]

9. Von Schomberg, R. Prospects for technology assessment in a framework of responsible research and innovation. In Technikfolgen Abschätzen Lehren; Dusseldorp, M., Beecroft, R., Eds.; VS Verlag für Sozialwissenschaften: Wiesbaden, Germany, 2012; pp. 39-61.

10. Owen, R.; Macnaghten, P.; Stilgoe, J. Responsible research and innovation: From science in society to science for society, with society. Sci. Public Policy 2012, 39, 751-760. [CrossRef]

11. Burget, M.; Bardone, E.; Pedaste, M. Definitions and Conceptual Dimensions of Responsible Research and Innovation: A Literature Review. Sci. Eng. Ethics 2017, 23, 1-19. [CrossRef] [PubMed]

12. Lettice, F.; Pawar, K.; Rogers, H. Responsible Innovation: What Challenges Does It Pose for the New Product Development Process? In Proceedings of the 19th International ICE \& IEEE-ITMC International Technology Management Conference, The Hague, The Netherlands, 24-26 June 2013.

13. Pellé, S.; Reber, B. Responsible Innovation Models Report; Current Theory and Practice. Available online: http:/ / www.great-project.eu/research/Responsible_Innovation_Model_Report_versionforsubmission. docx (accessed on 3 May 2017).

14. Blok, V.; Lemmens, P. The Emerging Concept of Responsible Innovation. Three Reasons Why It Is Questionable and Calls for a Radical Transformation of the Concept of Innovation. In Responsible Innovation 2; Koops, B.-J., Hoven, J., van den Romijn, H., Swierstra, T., Oosterlaken, I., Eds.; Springer: Cham, Switzerland, 2015; Volume 2, pp. 19-35.

15. Baregheh, A.; Rowley, J.; Sambrook, S. Towards a multidisciplinary definition of innovation. Manag. Decis. 2009, 47, 1323-1339. [CrossRef]

16. Choi, N.; Majumdar, S. Social Innovation: Towards a Conceptualisation. In Technology and Innovation for Social Change; Majumdar, S., Guha, S., Marakkath, N., Eds.; Springer: New Delhi, India, 2014; pp. 7-34.

17. Caulier-Grice, J.; Davies, A.; Patrick, R.; Norman, W. Social Innovation Overview: A Deliverable of the Project: "The Theoretical, Empirical and Policy Foundations for Building Social innovation in Europe"; European Commissioner: Brussels, Belgium, 2012.

18. Lubberink, R.; Blok, V.; van Ophem, J.; Omta, O. A Framework for Responsible Innovation in the Business Context: Lessons from Responsible-, Social- and Sustainable Innovation. In Responsible Innovation 3: A European Agenda? Asveld, L., van Dam-Miras, M.E.C., Swierstra, T., Lavrijssen, S.A.C.M., Linse, C.A., van den Hoven, J., Eds.; Springer: Dordrecht, The Netherlands, unpublished work.

19. Denyer, D.; Tranfield, D. Producing a Systematic Review. In The Sage Handbook of Organizational Research Methods; Buchanan, D., Bryman, A., Eds.; SAGE Publications Ltd.: London, UK, 2009; pp. 671-689.

20. Gough, D.; Oliver, S.; Thomas, J. (Eds.) An Introduction to Systematic Reviews; Sage Publications Limited: London, UK, 2012; pp. 1-16.

21. Zwart, H.; Landeweerd, L.; van Rooij, A. Adapt or perish? Assessing the recent shift in the European research funding arena from "ELSA" to "RRI". Life Sci. Soc. Policy 2014, 10, 11. [CrossRef] [PubMed] 
22. Gianni, R.; Goujon, P. WP2 Current Theory and Practice Task 2.3 Construction of an Analytical Grid; Current Theory and Practice. Available online: http://www.great-project.eu/deliverables_files/deliverables02 (accessed on 3 May 2017).

23. Wickson, F.; Carew, A.L. Quality criteria and indicators for responsible research and innovation: Learning from transdisciplinarity. J. Responsible Innov. 2014, 1, 254-273. [CrossRef]

24. Pavie, X.; Scholten, V.; Carthy, D. Responsible Innovation: From Concept to Practice; World Scientific Publishing Co. Pte. Ltd.: Signapore, 2014.

25. Papadopoulos, Y.; Warin, P. Are innovative, participatory and deliberative procedures in policy making democratic and effective? Eur. J. Political Res. 2007, 46, 445-472. [CrossRef]

26. Van de Kerkhof, M. Making a difference: On the constraints of consensus building and the relevance of deliberation in stakeholder dialogues. Policy Sci. 2006, 39, 279-299. [CrossRef]

27. Van Oudheusden, M. Where are the politics in responsible innovation? European governance, technology assessments, and beyond. J. Responsible Innov. 2014, 1, 67-86. [CrossRef]

28. Moulaert, F.; Martinelli, F.; Swyngedouw, E.; González, S. Towards alternative model(s) of local innovation. Urban Stud. 2005, 42, 1969-1990. [CrossRef]

29. Cajaiba-Santana, G. Social innovation: Moving the field forward. A conceptual framework. Technol. Forecast. Soc. Chang. 2014, 82, 42-51. [CrossRef]

30. Van der Have, R.P.; Rubalcaba, L. Social innovation research: An emerging area of innovation studies? Res. Policy 2016, 45, 1923-1935. [CrossRef]

31. Mumford, M.D. Social Innovation: Ten Cases From Benjamin Franklin. Creat. Res. J. 2002, 14, $253-266$. [CrossRef]

32. Schiederig, T.; Tietze, F.; Herstatt, C. Green innovation in technology and innovation management-An exploratory literature review. RED Manag. 2012, 42, 180-192.

33. Franceschini, S.; Faria, L.G.D.; Jurowetzki, R. Unveiling scientific communities about sustainability and innovation. A bibliometric journey around sustainable terms. J. Clean. Prod. 2016, 127, 72-83. [CrossRef]

34. Tranfield, D.; Denyer, D.; Smart, P. Towards a Methodology for Developing Evidence-Informed Management Knowledge by Means of Systematic Review. Br. J. Manag. 2003, 14, 207-222. [CrossRef]

35. Pawson, R.; Greenhalgh, T.; Harvey, G.; Walshe, K. Realist Synthesis: An Introduction; ESRC Research Methods Programme; University of Manchester: Manchester, UK, 2004.

36. Walshe, C.; Luker, K.A. District nurses' role in palliative care provision: A realist review. Int. J. Nurs. Stud. 2010, 47, 1167-1183. [CrossRef] [PubMed]

37. Boaz, A.; Ashby, D. Fit for Purpose? Assessing Research Quality for Evidence Based Policy and Practice; ESRC UK Centre for Evidence Based Policy and Practice: London, UK, 2003.

38. Rycroft-Malone, J.; McCormack, B.; Hutchinson, A.M.; DeCorby, K.; Bucknall, T.K.; Kent, B.; Schultz, A.; Snelgrove-Clarke, E.; Stetler, C.B.; Titler, M.; et al. Realist synthesis: Illustrating the method for implementation research. Implement. Sci. 2012, 7, 33. [CrossRef] [PubMed]

39. Gaziulusoy, A.I.; Boyle, C.; McDowall, R. System innovation for sustainability: A systemic double-flow scenario method for companies. J. Clean. Prod. 2013, 45, 104-116. [CrossRef]

40. Larson, A.L. Sustainable innovation through an entrepreneurship lens. Bus. Strateg. Environ. 2000, 9, 304-317. [CrossRef]

41. Chadha, A. Overcoming Competence Lock-In for the Development of Radical Eco-Innovations: The Case of Biopolymer Technology. Ind. Innov. 2011, 18, 335-350. [CrossRef]

42. Denford, J.S. Building knowledge: Developing a knowledge-based dynamic capabilities typology. J. Knowl. Manag. 2013, 17, 175-194. [CrossRef]

43. Bartlett, D. Embedding corporate responsibility: The development of a transformational model of organizational innovation. Corp. Gov. 2009, 9, 409-420. [CrossRef]

44. Bocken, N.; Short, S.; Rana, P.; Evans, S. A value mapping tool for sustainable business modelling. Corp. Gov. 2013, 13, 482-497. [CrossRef]

45. Chalmers, D.M.; Balan-Vnuk, E. Innovating not-for-profit social ventures: Exploring the microfoundations of internal and external absorptive capacity routines. Int. Small Bus. J. 2013, 31, 785-810. [CrossRef]

46. Steen, M.; Buijs, J.; Williams, D. the Role of Scenarios and Demonstrators in Promoting Shared Understanding in Innovation Projects. Int. J. Innov. Technol. Manag. 2014, 11, 21. [CrossRef] 
47. Rohrbeck, R.; Konnertz, L.; Knab, S. Collaborative business modelling for systemic and sustainability innovations. Int. J. Technol. Manag. 2013, 63, 4. [CrossRef]

48. Asante, K.; Owen, R.; Williamson, G. Governance of new product development and perceptions of responsible innovation in the financial sector: Insights from an ethnographic case study. J. Responsible Innov. 2014, 1, 9-30. [CrossRef]

49. Acs, Z.J.; Sany, J. Measuring the Social Value of Innovation: The Cases of Muhammad Yunus, Grameen Bank and Bill Gates, Microsoft. In Measuring the Social Value of Innovation: A Link in the University Technology Transfer and Entrepreneurship Equation; Emerald Group Publishing Limited: Bingley, UK, 2009; Volume 19, pp. 143-170.

50. Edwards-Schachter, M.E.; Matti, C.E.; Alcántara, E. Fostering Quality of Life through Social Innovation: A Living Lab Methodology Study Case. Rev. Policy Res. 2012, 29, 672-692. [CrossRef]

51. Ayuso, S.; Rodríguez, M.Á.A.; Ricart, J.E.; Miguel Ángel, R.; Ricart, J.E. Using stakeholder dialogue as a source for new ideas: A dynamic capability underlying sustainable innovation. Corp. Gov. 2006, 6, 475-490. [CrossRef]

52. Bocken, N.M.P.; Farracho, M.; Bosworth, R.; Kemp, R. The front-end of eco-innovation for eco-innovative small and medium sized companies. J. Eng. Technol. Manag. JET-M 2014, 31, 43-57. [CrossRef]

53. Füller, J.; Hutter, K.; Fries, M. Crowdsourcing for goodness sake: Impact of incentive preference on contribution behavior for social innovation. In Advances in International Marketing; Swan, K.S., Zou, S., Eds.; Emerald Group Publishing Ltd.: Bingley, UK, 2012; Volume 23, pp. 137-159.

54. Franke, N.; Keinz, P.; Klausberger, K. "Does This Sound Like a Fair Deal?": Antecedents and Consequences of Fairness Expectations in the Individual's Decision to Participate in Firm Innovation. Organ. Sci. 2013, 24, 1495-1516. [CrossRef]

55. Hansen, E.G.; Bullinger, A.C.; Reichwald, R. Sustainability innovation contests: Evaluating contributions with an eco impact-innovativeness typology Ralf Reichwald. Int. J. Innov. Sustain. Dev. 2011, 5, 221-245. [CrossRef]

56. Dossa, Z.; Kaeufer, K. Understanding Sustainability Innovations Through Positive Ethical Networks. J. Bus. Ethics 2014, 119, 543-559. [CrossRef]

57. Berker, T. Dealing with uncertainty in sustainable innovation: Mainstreaming and substitution. Int. J. Innov. Sustain. Dev. 2010, 5, 65-79. [CrossRef]

58. Biondi, V.; Iraldo, F.; Meredith, S. Achieving sustainability through environmental innovation: The role of SMEs. Int. J. Technol. Manag. 2002, 24, 612-626. [CrossRef]

59. Baba, Y.; Walsh, J.P. Embeddedness, social epistemology and breakthrough innovation: The case of the development of statins. Res. Policy 2010, 39, 511-522. [CrossRef]

60. Arnold, M.G.; Hockerts, K. The greening dutchman: Philips' process of green flagging to drive sustainable innovations. Bus. Strateg. Environ. 2011, 20, 394-407. [CrossRef]

61. Arnold, M. Corporate strategies for sustainable innovations. In Facilitating Sustainable Innovation through Collaboration; Springer: Dordrecht, The Netherlands, 2010; pp. 217-232.

62. Ortega, S.; Furr, N.; Liman, E.; Flint, C. The Science of Social Impact Innovation: How to Deliver More Impact through Innovative Business Models. Int. J. Innov. Sci. 2014, 6, 73-82. [CrossRef]

63. Wodzisz, R. Case Study of R-1234yf Refrigerant: Implications for the Framework for Responsible Innovation. Sci. Eng. Ethics 2015, 21, 1413-1433. [CrossRef] [PubMed]

64. Weisenfeld, U. Corporate social responsibility in innovation: Insights from two cases of Syngenta's activities in genetically modified organisms. Creat. Innov. Manag. 2012, 21, 199-211. [CrossRef]

65. Heidi von Weltzien, H. Embedding CSR as a learning and knowledge creating process: The case for SMEs in Norway. J. Manag. Dev. 2011, 30, 1067-1084. [CrossRef]

66. Eccles, R.G.; Serafeim, G. The performance frontier: Innovating for a sustainable strategy. Harv. Bus. Rev. 2013, 91, 1-10.

67. Andersson, E.R.; Lundblad, J.; Jansson, B. A public arena for sustainable health and safety innovation: Guidelines for research and practice. Int. J. Innov. Sustain. Dev. 2012, 6, 324-343. [CrossRef]

68. Elmquist, M.; Segrestin, B. Sustainable development through innovative design: Lessons from the KCP method experimented with an automotive firm. Int. J. Automot. Technol. Manag. 2009, 9, 229-244. [CrossRef]

69. Joore, P. The V-Cycle for system innovation translating a broad societal need into concrete product service solutions: the multifunctional centre Apeldoorn case. J. Clean. Prod. 2008, 16, 1153-1162. [CrossRef] 
70. Halme, M.; Korpela, M. Responsible Innovation Toward Sustainable Development in Small and Medium-Sized Enterprises: a Resource Perspective. Bus. Strateg. Environ. 2014, 23, 547-566. [CrossRef]

71. Spena, T.R.; Chiara, A. De CSR, innovation strategy and supply chain management: toward an integrated perspective. Int. J. Technol. Manag. 2012, 58, 83-108. [CrossRef]

72. Halila, F.; Rundquist, J. The development and market success of eco-innovations: A comparative study of eco-innovations and "other" innovations in Sweden. Eur. J. Innov. Manag. 2011, 14, 278-302. [CrossRef]

73. Doran, J. Regulation and firm perception, eco-innovation and firm performance. Eur. J. Innov. Manag. 2012, 15, 421-441. [CrossRef]

74. Kesidou, E.; Demirel, P. On the drivers of eco-innovations: Empirical evidence from the UK. Res. Policy 2012, 41, 862-870. [CrossRef]

75. Van Osch, W.; Avital, M. The road to Sustainable Value: The path-dependent construction of sustainable innovation as sociomaterial practices in the car industry. In Positive Design and Appreciative Construction: From Sustainable Development to Sustainable Value; Thatchenkery, T., Cooperrider, D.L., Avital, M., Eds.; Emerald Group Publishing Limited: Bingley, UK, 2010; Volume 3, pp. 99-116.

76. Parry, S. Going green: The evolution of micro-business environmental practices. Bus. Ethics 2012, 21, $220-237$. [CrossRef]

77. Bos-Brouwers, H.E.J. Corporate sustainability and innovation in SMEs: Evidence of themes and activities in practice. Bus. Strateg. Environ. 2010, 19, 417-435. [CrossRef]

78. Harrisson, D.; Chaari, N.; Comeau-Vallée, M.; Comeau-Vallee, M. Intersectoral Alliance and Social Innovation: When Corporations Meet Civil Society. Ann. Public Coop. Econ. 2012, 83, 1-24. [CrossRef]

79. Kanter, R.M. From spare change to real change. The social sector as beta site for business innovation. Harv. Bus. Rev. 1999, 77, 122-132, 210. [PubMed]

80. Lampikoski, T.; Westerlund, M.; Rajala, R.; Möller, K. Green Innovation Games: Value-creation strategies for corporate sustainability. Calif. Manag. Rev. 2014, 57, 88-116. [CrossRef]

81. Wilson, F.; Post, J.; Grzywinski, R.; Houghton, M. Social innovation and investment: The ShoreBank experience. Crit. Stud. Corp. Responsib. Gov. Sustain. 2014, 7, 65-89.

82. Lettice, F.; Parekh, M. The social innovation process: Themes, challenges and implications for practice. Int. J. Technol. Manag. 2010, 51, 139-158. [CrossRef]

83. Pujari, D. Eco-innovation and new product development: Understanding the influences on market performance. Technovation 2006, 26, 76-85. [CrossRef]

84. Bridgstock, R.; Lettice, F.; Özbilgin, M.F.; Tatli, A.; Oezbilgin, M.F.; Tatli, A. Diversity management for innovation in social enterprises in the UK. Entrep. Reg. Dev. 2010, 22, 557-574. [CrossRef]

85. Blok, V.; Hoffmans, L.; Wubben, E.F.M. Stakeholder Engagement for Responsible Innovation in the Private Sector: Critical Issues and Management Practices. J. Chain Netw. Sci. 2015, 15, 147-164. [CrossRef]

86. Le Ber, M.J.; Branzei, O. (Re)Forming Strategic Cross-Sector Partnerships: Relational Processes of Social Innovation. Bus. Soc. 2009, 49, 140-172. [CrossRef]

87. Stuermer, M.; Spaeth, S.; von Krogh, G. Extending private-collective innovation: a case study. RED Manag. 2009, 39, 170-191.

88. Wagner, M. The links of sustainable competitiveness and innovation with openness and user integration: An empirical analysis. Int. J. Innov. Sustain. Dev. 2009, 4, 314-329. [CrossRef]

89. Balka, K.; Raasch, C.; Herstatt, C. The effect of selective openness on value creation in user innovation communities. J. Prod. Innov. Manag. 2014, 31, 392-407. [CrossRef]

90. Ciasullo, M.V.; Troisi, O. Sustainable value creation in SMEs: A case study. TQM J. 2013, 25, 44-61. [CrossRef]

91. Ornetzeder, M. Old technology and social innovations. Inside the Austrian success story on solar water heaters. Technol. Anal. Strateg. Manag. 2001, 13, 105-115. [CrossRef]

92. Jamali, D.; Yianni, M.; Abdallah, H. Strategic partnerships, social capital and innovation: Accounting for social alliance innovation. Bus. Ethics 2011, 20, 375-391. [CrossRef]

93. Walter, A.I.; Scholz, R.W. Sustainable innovation networks: An empirical study on interorganisational networks in industrial ecology. Prog. Ind. Ecol. An Int. J. 2006, 3, 431-450. [CrossRef]

94. Lopez-Berzosa, D.; Gawer, A. Innovation policy within private collectives: Evidence on 3GPP's regulation mechanisms to facilitate collective innovation. Technovation 2014, 34, 734-745. [CrossRef]

95. Carrillo-Hermosilla, J.; Del Río, P.; Könnölä, T. Diversity of eco-innovations: Reflections from selected case studies. J. Clean. Prod. 2010, 18, 1073-1083. [CrossRef] 
96. Haen, D.; Sneijder, P.; te Molder, H.; Swierstra, T. Natural Food: Organizing "Responsiveness" in Responsible Innovation of Food Technology. In Responsible Innovation 2; Koops, B.-J., Oosterlaken, I., Romijn, H., Swierstra, T., van den Hoven, J., Eds.; Springer: Cham, Switzerland, 2015; pp. 161-181.

97. Limburg, D. Social Innovation through Information Provision. In Human Resource Management, Social Innovation and Technology; Emerald Group Publishing Ltd.: Bingley, UK, 2014; Volume 14, pp. 21-36.

98. Blum-Kusterer, M.; Hussain, S.S. Innovation and corporate sustainability: An investigation into the process of change in the pharmaceuticals industry. Bus. Strateg. Environ. 2001, 10, 300-316. [CrossRef]

99. Kinder, T. Social innovation in services: Technologically assisted new care models for people with dementia and their usability. Int. J. Technol. Manag. 2010, 51, 106-120. [CrossRef]

100. Kiron, D.; Kruschwitz, N.; Reeves, M.; Goh, E. The Benefits of Sustainability-Driven Innovation. MIT Sloan Manag. Rev. 2013, 54, 69-73.

101. Richter, M. Business model innovation for sustainable energy: German utilities and renewable energy. Energy Policy 2013, 62, 1226-1237. [CrossRef]

102. Evans, S.; Partidário, P.J.; Lambert, J.; Partidario, P.J.; Lambert, J. Industrialization as a key element of sustainable product-service solutions. Int. J. Prod. Res. 2007, 45, 4225-4246. [CrossRef]

103. Riivari, E.; Lämsä, A.M. Does it Pay to Be Ethical? Examining the Relationship Between Organisations' Ethical Culture and Innovativeness. J. Bus. Ethics 2013, 124, 1-17. [CrossRef]

104. Ruppel, C.P.; Harrington, S.J. The relationship of communication, ethical work climate, and trust to commitment and innovation. J. Bus. Ethics 2000, 25, 313-328. [CrossRef]

105. Halme, M.; Korpela, M. Scarcity or abundance? Examination of resources behind responsible innovation in small enterprises. Acad. Manag. Proc. 2013, 2013, 12877. [CrossRef]

106. Scholten, V.E.; van der Duin, P.A. Responsible Innovation among Academic Spin-Offs: How Responsible Practices Help Developing Absorptive Capacity. J. Chain Netw. Sci. 2015, 15, 165-179. [CrossRef]

107. Ketata, I.; Sofka, W.; Grimpe, C. The role of internal capabilities and firms' environment for sustainable innovation: Evidence for Germany. RED Manag. 2014, 45, 60-75.

108. Ziv, N.D. An exploration on community-based innovation: Indaba music as a case in point. In Proceedings of the Portland International Conference on Management of Engineering \& Technology, PICMET 2008, Cape Town, South Africa, 27-31 July 2008; pp. 593-602.

109. Arentshorst, M.E.; Broerse, J.E.W.; Roelofsen, A.; de Cock Buning, T. Towards responsible neuroimaging applications in health care: Guiding visions of scientists and technology developers. In Responsible Innovation 1: Innovative Solutions for Global Issues; Springer: Dordrecht, The Netherlands, 2014; pp. 255-280.

110. Flipse, S.M.; van der Sanden, M.C.A.; Osseweijer, P. Midstream modulation in biotechnology industry: Redefining what is "part of the job" of researchers in industry. Sci. Eng. Ethics 2013, 19, 1141-1164. [CrossRef] [PubMed]

111. Foley, R.W.; Bernstein, M.J.; Wiek, A. Towards an alignment of activities, aspirations and stakeholders for responsible innovation. J. Responsible Innov. 2016, 3, 209-232. [CrossRef]

112. Iatridis, K.; Schroeder, D. Applying Corporate Responsibility Tools to Responsible Research and Innovation. In Responsible Research and Innovation in Industry; Springer Briefs in Research and Innovation Governance; Springer: Cham, Switzerland, 2016; pp. 65-81.

113. Res-AGorA. Navigating Towards Shared Responsibility in Research and Innovation Approach, Process and Results of the Res-AGorA Project; Fraunhofer Institute for Systems and Innovation Research ISI: Karlsruhe, Germany, 2016.

114. Schrammel, M.; Hofer, M.; Marschalek, I.; Unterfrauner, E.; Voigt, C.; Schuch, K.; Siller, C. D.5.3-Validation Report on the RRI Toolkit. Available online: https:/ / www.rri-tools.eu/documents/10184/107098/RRITools_ D5+3-Validation+Report+on+the+RRI+Toolkit.pdf/0dbb3404-814f-4bdf-adba-271cc60238b3 (accessed on 3 May 2017).

115. Porcari, A.; Borsella, E.; Mantovani, E. Responsible-Industry: A Framework for Implementing Responsible Research and Innovation in ICT for an Ageing Society; Italian Association for Industrial Research: Rome, Italy, 2015.

116. Pandza, K.; Ellwood, P. Strategic and ethical foundations for responsible innovation. Res. Policy 2013, 42, 1112-1125. [CrossRef]

117. Schumacher, E.G.; Wasieleski, D.M. Institutionalizing Ethical Innovation in Organizations: An Integrated Causal Model of Moral Innovation Decision Processes. J. Bus. Ethics 2013, 113, 15-37. [CrossRef] 
118. Zahra, S.; Gedajlovic, E.; Neubaum, D.; Shulman, J. A typology of social entrepreneurs: Motives, search processes and ethical challenges. J. Bus. Ventur. 2009, 24, 519-532. [CrossRef]

119. Von Schomberg, R. Responsible Innovation 1; van den Hoven, J., Doorn, N., Swierstra, T., Koops, B.-J., Romijn, H., Eds.; Springer: Dordrecht, The Netherlands, 2014.

120. Mulgan, G.; Tucker, S.; Ali, R.; Sanders, B. Social Innovation: What It Is, Why It Matters and How It Can Be Accelerated. Available online: http://eureka.sbs.ox.ac.uk/761/1/Social_Innovation.pdf (accessed on 3 May 2017).

121. Charter, M.; Clark, T. Sustainable Innovation: Key Conclusions from Sustainable Innovation Conferences 2003-2006 Organised by the Centre for Sustainable Design. Available online: http://cfsd.org.uk/ Sustainable\%20Innovation/Sustainable_Innovation_report.pdf (accessed on 3 May 2017).

122. Mulgan, G. The Process of Social Innovation. Innov. Technol. Gov. Glob. 2006, 1, 145-162. [CrossRef]

123. Sharra, R.; Nyssens, M. Social Innovation: An Interdisciplinary and Critical Review of the Concept. Available online: http:/ / farm.tudor.lu/sites/default/files/2009_SI_anInterdisciplinary\%26CriticalReviewofConcept_ Sharra-Nyssens.pdf (accessed on 3 May 2017).

124. Boons, F.; Montalvo, C.; Quist, J.; Wagner, M. Sustainable innovation, business models and economic performance: An overview. J. Clean. Prod. 2013, 45, 1-8. [CrossRef]

125. Dawson, P.; Daniel, L. Understanding social innovation: A provisional framework. Int. J. Technol. Manag. 2010, 51, 9. [CrossRef]

126. Chalmers, D. Social innovation: An exploration of the barriers faced by innovating organizations in the social economy. Local Econ. 2013, 28, 17-34. [CrossRef]

127. Boons, F.; Lüdeke-Freund, F. Business models for sustainable innovation: State-of-the-art and steps towards a research agenda. J. Clean. Prod. 2013, 45, 9-19. [CrossRef]

128. Draper, S. Creating the Big Shift: System Innovation for Sustainability; Forum for the Future: London, UK, 2013; Available online: https:/ / www.forumforthefuture.org/sites/default/files/images/Forum/Documents / SI\%20document\%20v4.2\%20web\%20spreads_1.pdf (accessed on 3 May 2017).

(C) 2017 by the authors. Licensee MDPI, Basel, Switzerland. This article is an open access article distributed under the terms and conditions of the Creative Commons Attribution (CC BY) license (http:/ / creativecommons.org/licenses/by/4.0/). 